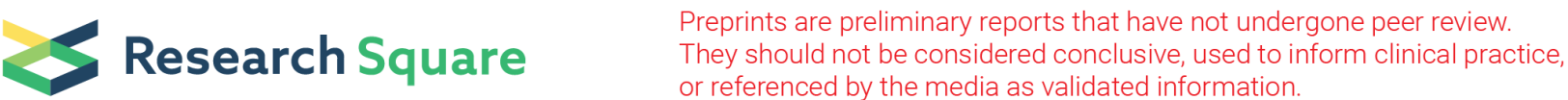

\section{Design and synthesis of novel pyrazole-benzofuran hybrids: in vitro a-glucosidase inhibitory activity, kinetic and molecular modeling study}

\section{Fateme Azimi}

Isfahan University of Medical Science

Homa Azizian

University of Medical Science

Mohammad Najafi

Isfahan University of Technology

Ghadamali khodarahmi

Isfahan University of Medical Science

Motahareh hassanzadeh

Isfahan University of Medical Science

\section{Lotfollah Saghaei}

Isfahan University of Medical Science

Jahan B. Ghasemi

University of Tehran

Hojjat Sadeghi-aliabadi

Isfahan University of Medical Science

Mohammad Ali Faramarzi

Tehran University of Medical Sciences

\section{Bagher Larijani}

Tehran University of Medical Sciences

Farshid Hassanzadeh ( $\nabla$ hassanzadeh@pharm.mui.ac.ir)

Isfahan University of Medical Science

Mohammad Mahdavi

Tehran University of Medical Sciences

\section{Research Article}

Keywords: a-Glycosidase inhibitor, Pyrazole, Benzofuran, Enzyme kinetic study, Molecular dynamic simulation

Posted Date: March 17th, 2021 
DOI: https://doi.org/10.21203/rs.3.rs-288227/v1

License: (c) (1) This work is licensed under a Creative Commons Attribution 4.0 International License. Read Full License 


\section{Abstract}

In this work, new derivatives of biphenyl pyrazole-benzofuran hybrids designed, synthesized and evaluated in vitro through enzymatic assay for inhibitory effect against a-glucosidase activity. Newly identified inhibitors were found to be four to eighteen folds more active with $\mathrm{IC}_{50}$ values in the range of $40.6 \pm 0.2-164.3 \pm 1.8 \mu \mathrm{M}$, as compared to the standard drug acarbose $\left(\mathrm{IC}_{50}=750.0 \pm 10.0 \mu \mathrm{M}\right)$. Limited Structure-activity relationship was established. A kinetic binding study indicated that most active compound $8 \mathrm{e}$ acted as the competitive inhibitors of a-glucosidase with $\mathrm{Ki}=38 \mu \mathrm{M}$. Molecular docking has also been performed to find the interaction modes responsible for the desired inhibitory activity. As expected, all pharmacophoric features used in the design of the hybrid, are involved in the interaction with the active site of the enzyme. In addition, molecular dynamic simulations showed compound 8e oriented vertically into the active site from mouth to the bottom and stabilized the enzyme domains by interacting with the interface of domain $A$ and domain $B$ and the back side of the active site while acarbose formed non-binding interaction with the residue belong to the domain $A$ of the enzyme.

\section{Introduction}

a-glucosidases (EC 3.2.1.20) is a membrane-bound enzyme in the brush border of the intestine which hydrolyses oligosaccharides and polysaccharide to D-glucose, as only monosaccharides can be absorbed from the intestinal lumen ${ }^{1}$. Inhibition of a-glucosidase can retard the release of glucose from complex carbohydrates and therefore can be an important strategy to control hyperglycemia in type-2 diabetes. In addition, the role of cellular a-glucosidase in carbohydrate processing caused that the inhibitors of a-glucosidase also regarded as a convincing therapeutic target for the development of novel drugs for the treatment of numerous diseases including cancer and viral infections ${ }^{2-4}$. Accordingly, acarbose (Glucobay), miglitol (Glyset), and voglibose (Volix, Basen) are the commercially available $a$ glucosidase inhibitors and are recommended as first-line drugs for the treatment of type-2 diabetes ${ }^{5}$. Due to the sugar-based structure of mentioned a-glucosidase inhibitors, their synthesis needs complicated multistep procedures ${ }^{6}$. Unfortunately, administration of these inhibitors is associated with undesirable side effects including diarrhea, abdominal discomfort, and flatulence ${ }^{7,8}$. Thus, it would be essential to develop novel, safe, and efficient $a$-glucosidase inhibitors as an effective lead candidate for future antidiabetic drug discovery initiatives.

Pyrazole and its derivatives are one of the most important heterocyclic framework in medicinal chemistry possessing a broad spectrum of pharmacological activities like anti-inflammatory, anti-tubercular, antitumor, antibacterial, anti-Alzheimer's, antileishmanial, and antihypertensive activities ${ }^{9}$. Over the last years, several well-known drugs that possess pyrazole scaffold like Celecoxib, Viagra, Fipronil, etc., are in clinical use as therapeutic agents ${ }^{10-12}$. Therefore pyrazole nucleus served as a valuable candidate for the exploration of lead molecules. Historically, different derivative of substituted pyrazole has been introduced as anti hypoglycemic agent ${ }^{13}$. Also recently, several pyrazole-containing agents have been reported as potent antidiabetic ${ }^{14-16}$ and hypoglycemic ${ }^{17-19}$ agents. For instance, Munawar et al. 
reported a new series of imidazolylpyrazole derivatives as potent a-glucosidase inhibitor (Fig. 1 compound A) ${ }^{20}$ and Xiong et al. discovered the pyrazole-containing derivatives as highly potent and selective glucagon receptor antagonist (Fig. 1 compound B) ${ }^{21}$. It is noteworthy that "Teneligliptin", antidiabetic drug containing pyrazole, was approved for the treatment of type-II diabetes ${ }^{22}$. In addition to the success of this scaffold in the chemical class of anti-diabetic reagents, significant metabolic stability and pharmacological efficiency of pyrazole-based antidiabetic agents encouraged us to further study pyrazole scaffolds to develop a new agent ${ }^{23}$.

On the other hand, interesting physiological and chemotherapeutic properties of benzofuran scaffolds make them promising pharmacophore to design and develop new potentially useful therapeutic agents

${ }^{24}$. Moreover, several benzofuran derivatives with a-glucosidase inhibitory activity have been reported. Mphahlele et al. design and synthesis 2-arylbenzofuran-selanadiazole hybrids and evaluated them in vitro through enzymatic assays for inhibitory effect against a-glucosidase (Fig. 1 compound C) ${ }^{25}$. Dimer structures of nature-mimicking hydroxybenzofuran methyl ketones have been evaluated for antidiabetic activity through inhibition of protein tyrosine phosphatase-1B (PTP-1B), which is a legitimate target for the treatment of Type 2 diabetes (Fig. 1 compound D) ${ }^{26}$. Spasov et al. have reported 2-acylbenzofurans as potent a-glucosidase inhibitors (Fig. 1 compound E) ${ }^{27}$.

Over the years, molecular hybridization has been extensively used as the most efficient strategy for the design of novel a-glucosidase inhibitors. It is expected that pharmacophoric hybridization facilitate the development of new compounds with improved affinity and efficacy. On the other hand, previous studies have shown that p-stacking and hydrophobic effect play key roles in promoting inhibitory activity of the new compounds against a-glucosidase enzyme ${ }^{28,29}$. Therefore, the pyrazole ring with two attached phenyl groups was incorporated in the design to provide favorable hydrophobic interactions. Hence, prompted by above observations and in continuation to our attempt in development of a-glucosidase inhibitors, we designed the skeleton of biphenyl pyrazole-benzofuran and evaluation their a-glucosidase inhibition potential ${ }^{30-34}$ (Fig. 1).

Apart from in vitro assessment of target compounds, the mechanism underlying enzymatic inhibition of the most potent compound was further explored using kinetic analysis. Docking studies and molecular dynamic simulation have been performed to determine plausible protein-ligand interactions.

\section{Results And Discussion}

\subsection{Chemistry}

The synthetic pathway for the preparation of iphenyl pyrazole-benzofuran hybrid $8 \mathrm{a}-0$ is outlined in Scheme 1. The hydrazones $8 \mathrm{a}-\mathrm{o}$ were prepared by the condensation reaction of the acetophenone derivatives 1 with the phenylhydrazine or 4-methyl phenylhydrazine hydrochloride 2 under reflux condition in absolute ethanol and in the presence of a catalytic amount of sulfuric acid. Intermediate hydrazone 
derivatives 3a-o were converted into 4-formyl pyrazole derivatives 4a-o by applying Vilsmeier-Haack reaction with $\mathrm{POCl}_{3}-\mathrm{DMF}$. On the other hand, benzofuran-2-carbohydrazide 7 was prepared by following reaction scheme. Initially, a mixture of salicylaldehyde 5 with ethyl bromoacetate heated at reflux in acetonitrile in the presence of potassium carbonate to afford ethyl benzofuran-2-carboxylate 6 . Then, refluxing the ethanolic solution of the ethyl ester 6 and hydrazine hydrate yielded benzofuran-2carbohydrazide 7. Finally, desired products were obtained by coupling the hydrazide 7 with key aldehydes $4 a-o$ in absolute ethanol and in the presence of glacial acetic acid. The structures of newly synthesized compounds were confirmed by their IR, ${ }^{1} \mathrm{H}$ NMR, ${ }^{13} \mathrm{C}$ NMR, and elemental analysis ${ }^{25,35}$.

\subsection{In vitro a-glucosidase inhibitory activity}

All of the newly synthesized compounds $8 a-0$ were screened for a-glucosidase inhibition activity. aGlucosidase enzyme from (Saccharomyces cerevisiae, EC3.2.1.20) was used to evaluate the aglucosidase inhibitory activity. Compared to human a-glucosidase, they shared similarity in substrate specificity, $\mathrm{pH}$ optimum, catalytic residues in active site and inhibitor sensitivity ${ }^{36}$. Therefore, aglucosidase from yeast is extensively used for the preliminary screening of a-glucosidase inhibitors ${ }^{37,38}$. Acarbose, a commercially available a-glucosidase inhibitor, was used as the reference drug and the results are expressed as $\mathrm{IC}_{50}$ values (Table 1). Albeit, all pharmacophoric groups in the designed hybrid seem to have involved in the inhibitory potential but to further elucidate the role of substituents on the aryl rings connected to pyrazole, a wide variety of compounds 8 were synthesized and structure-activity relationship (SAR) has been established on the basis of varying substituents in $R_{1}$ and $R_{2}$. Accordingly, SAR was investigated in two categories of $8 a-i\left(\right.$ Table $1, R_{2}=H$ ) and 8j-o (Table $1, R_{2}=C_{3}$ ). It is worth mentioning that all synthetic compounds showed significant activity with $\mathrm{IC}_{50}$ values in the range of 40.6 $\pm 0.2-164.3 \pm 1.8 \mu \mathrm{M}$, when compared to acarbose $(750.0 \pm 10.0 \mu \mathrm{M})$. Among them compound $8 \mathrm{e}\left(\mathrm{IC}_{50}=\right.$ $40.6 \pm 0.2 \mu \mathrm{M})$, having a nitro group in $R_{1}$ position, was found to be the most potent inhibitor. This is approximately eighteen-fold more potent than the standard acarbose. The introduction of other electronwithdrawing groups, such as halogen atoms and trifluoromethyl (8f-i), led to the reduction of inhibitory activity. Halogenated counterparts of compound $8 \mathrm{e}$ in the first category of compounds, exhibited inhibitory activity generally depending on the size of halogen substitution. Compound $8 f\left({ }^{2} C_{50}=79.7 \pm 0.5\right.$ $\mu \mathrm{M}$ ) bearing bromo substituent was found to be the second most active analog in this category and ninefold more potent than standard. Compounds $8 \mathrm{~g}$ having a relatively large chlorine substituent and $8 \mathrm{~h}$ having a small fluorine group showed lower activities with $\mathrm{IC}_{50}$ values of $125.3 \pm 1.0$ and $164.3 \pm 1.8 \mu \mathrm{M}$, respectively. It should be noted that change the fluoro group with trifluoromethyl moiety as in the case of compound $8 \mathrm{i}\left(\mathrm{IC}_{50}=101.7 \pm 0.7 \mu \mathrm{M}\right)$, led to a significant improvement in the inhibition potential. Finally, the order of inhibition for compounds $8 a-d$ was $8 c>8 b>8 d>8 a\left(I_{50 s}=100.3 \pm 0.7,108.3 \pm 0.8,133.6 \pm\right.$ 1.2 , and $141.2 \pm 1.4 \mu \mathrm{M}$, respectively), which illustrated that inhibitory activity almost affected by the electron-donating property of substituent.

For further investigation the SAR, second category of compounds 8j-o possessing methyl group in $\mathrm{R}_{2}$ were also examined. Compound $8 \mathrm{I}\left(\mathrm{IC}_{50}=54.7 \pm 0.3 \mu \mathrm{M}\right)$ containing methoxy group was found to be the 
most active compound in this series. Also, this compound is the second most potent among the screened compounds and $>13$ folds more active than the standard. Replacement of methoxy group in 81 with methyl $\left(8 \mathrm{k}, \mathrm{IC}_{50}=115.6 \pm 0.9 \mu \mathrm{M}\right)$ or hydroxyl group $\left(8 \mathrm{~m}, \mathrm{IC}_{50}=127.0 \pm 1.0 \mu \mathrm{M}\right)$ resulted in a remarkable decrease the biological activity. The bromo substituted derivative $8 \mathrm{n}$ was found as the second most potent molecule among this series of compounds and exhibited approximately eight-fold enhanced activity as compared to the standard acarbose. So, as mentioned in the previous sections, the size of the bromine may be responsible for the higher activity of brominated compounds than other halogens.

It can be concluded that the in vitro a-glucosidase inhibitory activity mainly depends upon the substituents on $\mathrm{R}_{1}$ and the nature of substituents at this position affected the efficacy of methyl group on $R_{2}$. In this regard, the a-glucosidase inhibitory activity of bromine $(8 f, 8 n)$ and chlorine $(8 g, 80)$ substituted analogs in two series of mentioned compounds revealed that the introduction of methyl groups on $\mathrm{R}_{2}$ led to lower activity $(8 f>8 n$ and $8 g>80$ ). Similarly, the lack of methyl group in the case of compound $8 k$ resulted in a slight decreased in inhibitory activity as compound $8 \mathrm{~b}$. In a different manner, compound $8 \mathrm{I}$ was more active than compound $8 \mathrm{c}$. Both compounds have a methoxy group at the $\mathrm{R}_{1}$ position but the presence of the methyl group on $\mathrm{R}_{2}$ in compound 8 l led to a two-fold increase in activity. The same is the case of compounds $8 \mathrm{~d}$ and $8 \mathrm{~m}$ having hydroxyl group, the methyl substituent on $\mathrm{R}_{2}$ position was found to confer an increase in inhibitory activity.

\section{Table 1}

In vitro $\alpha$-glucosidase inhibitory activity of compounds 8a-p.

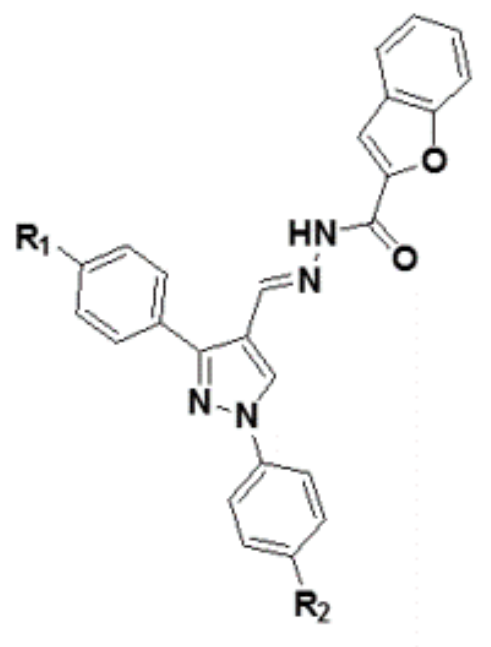

8a-n 


\begin{tabular}{|c|c|c|c|c|c|c|c|}
\hline Compd. & $\mathrm{R}_{1}$ & $\mathbf{R}_{2}$ & $\mathrm{IC}_{50}(\mu \mathrm{M})^{\mathrm{a}}$ & Compd. & $\mathrm{R}_{1}$ & $\mathrm{R}_{2}$ & $\mathrm{IC}_{50}(\mu \mathrm{M})^{\mathrm{a}}$ \\
\hline $8 a$ & $\mathrm{H}$ & $\mathrm{H}$ & $141.2 \pm 1.4$ & $8 \mathrm{j}$ & $\mathrm{H}$ & $\mathrm{CH}_{3}$ & $157.1 \pm 1.6$ \\
\hline $8 b$ & $\mathrm{CH}_{3}$ & $\mathrm{H}$ & $108.3 \pm 0.8$ & $8 \mathrm{k}$ & $\mathrm{CH}_{3}$ & $\mathrm{CH}_{3}$ & $115.6 \pm 0.9$ \\
\hline $8 c$ & $\mathrm{OCH}_{3}$ & $\mathrm{H}$ & $100.3 \pm 0.7$ & 81 & $\mathrm{OCH}_{3}$ & $\mathrm{CH}_{3}$ & $54.7 \pm 0.3$ \\
\hline $8 d$ & $\mathrm{OH}$ & $\mathrm{H}$ & $133.6 \pm 1.2$ & $8 \mathrm{~m}$ & $\mathrm{OH}$ & $\mathrm{CH}_{3}$ & $127.0 \pm 1.0$ \\
\hline $8 e$ & $\mathrm{NO}_{2}$ & $\mathrm{H}$ & $40.6 \pm 0.2$ & $8 n$ & $\mathrm{Br}$ & $\mathrm{CH}_{3}$ & $95.6 \pm 0.6$ \\
\hline $8 f$ & $\mathrm{Br}$ & $\mathrm{H}$ & $79.7 \pm 0.5$ & 80 & $\mathrm{Cl}$ & $\mathrm{CH}_{3}$ & $154.7 \pm 1.6$ \\
\hline $8 g$ & $\mathrm{Cl}$ & $\mathrm{H}$ & $125.3 \pm 1.0$ & acarbose & - & - & $750.0 \pm 10.0$ \\
\hline $8 \mathrm{~h}$ & $\mathrm{~F}$ & $\mathrm{H}$ & $164.3 \pm 1.8$ & & & & \\
\hline $8 \mathrm{i}$ & $\mathrm{CF}_{3}$ & $\mathrm{H}$ & $101.7 \pm 0.7$ & & & & \\
\hline
\end{tabular}

a Values are the mean \pm SD. All experiments were performed at least three times.

\subsection{Kinetic study}

To gain further insight into the mechanism of action of the synthesized compounds against aglucosidase, kinetics analysis was performed on the most potent compound $8 \mathrm{e}$. In different concentrations of test compound $(0,10,25$, and $40 \mu \mathrm{M})$ and with the incremental concentration (2-10 $\mathrm{mM}$ ) of substrate, the rate of the enzyme activity was calculated. The type of inhibition and experimental inhibition constant $\left(K_{i}\right)$ value were determined by employing Lineweaver-Burk plots and secondary replot of these plots, respectively. The Lineweaver-Burk plot showed that with varying concentrations of compound $8 \mathrm{e}, \mathrm{V}_{\max }$ of enzyme gradually increased without affecting the $\mathrm{K}_{\mathrm{m}}$ of enzyme (Fig. 2a). This pattern indicates a competitive type of inhibition. The plot of the slope of lines in the Lineweaver-Burk plots $\left(\mathrm{k}_{\mathrm{m}}\right)$ against the inhibitor concentration gave an approximation of the inhibition constant, $K_{i}$ of 38 $\mu \mathrm{M}$ for compounds $8 \mathrm{e}$ (Fig. 2b).

\subsection{Homology modeling and molecular docking study}

Molecular docking studies were also performed to rationalize the results of biological assays and gain structural insight into the binding of the synthetic derivatives against $a$-glucosidase. Due to the unavailability of the crystallographic structure of a-glucosidase from S. cerevisiae, the 3D structure of aglucosidase was modeled using MODELER inbuilt in Discovery Studio (DS) package and synthetic compounds were docked against established homology model. For this purpose, the FASTA format of the primary sequence was downloaded from Uniprot (Access code P53341) and submitted to NCBI BLAST to get a template with a suitable identity for sequence alignment ${ }^{39}$. Isomaltase from S. cerevisiae (PDB ID: $3 \mathrm{~A} 4 \mathrm{~A}$ ) with $71.4 \%$ identity and $86.7 \%$ similarity was selected as the template for modeling ${ }^{40}$. The best 
model was selected based on the lowest PDF Total Energy (3270.6404) and DOPE Scores (-73110.257813) and evaluated for further validation. The PROCHECK program was applied to assess the stereochemical quality of the model. The phi/psi Ramachandran plot distributions indicated that $99.6 \%$ residues are in the favored and allowed regions and only $0.2 \%$ residues lies in the outlier region (Fig. 3 ).

The superposed structure of acarbose (standard inhibitor) and the predicted top-scored conformation of the most potent compound $8 \mathrm{e}$ in the active site of a homology model of $a$-glucosidase was shown in Fig. 4 (left). The detailed binding mode of acarbose showed that it formed hydrogen bonding interactions with residues Asp349, His239, Asp68, Pro309, Glu304, Arg439, Arg212, Glu276 and one hydrophobic interaction with Phe157 (Fig. 4, right).

The theoretical binding mode of most active compounds $8 \mathrm{e}, 8 \mathrm{l}, 8 \mathrm{f}$ and $8 \mathrm{n}$ were also shown in Figs. 5 . Binding mode analysis showed that the following interactions are common among these compounds: (1) Pyrazole moiety interacts with Glu276 through $\pi$-anion binding. (2) Phenyl groups attached to the pyrazole moiety, on the other hand, are involved in hydrophobic interactions with Arg439, Ala278 and Tyr71. (3) The carbonyl oxygen of the amide group formed hydrogen bonds with the hydroxyl group of Tyr313, and (4) the planar benzofuran scaffold interacted with Arg312 via r-alkyl interaction. As expected, all pharmacophoric features used in the design of the hybrid, are involved in the interaction with the active site of the enzyme. The most potent compound $8 \mathrm{e}$ establishes more interactions with the residues in the binding pocket. The nitro substituent of this compound created a hydrogen bond with Arg439 and also two electrostatic interactions with Asp68 and Tyr71. Besides, the N1-phenyl ring of pyrazole moiety and benzofuran also formed hydrophobic interactions with Leu218 and Phe157, respectively, which leads to a snug fit at the binding site (Fig. 5a). When the interaction mode of compound $8 \mathrm{l}$ as the second most potent compound is compared to that of compound $8 \mathrm{e}$, only one hydrogen bond with Asp68 stabilizes diphenyl pyrazole moiety in 81 while in compound $8 \mathrm{e}$ the electrostatic interactions play an important role in binding of this moiety to the enzyme. Methyl substituent in compound 81 is located in a hydrophobic pocket formed by residues Leu218, His245, His279, Phe300 and Ala278 (Fig. 5b). In the case of compounds $8 f$ and 8n, both have bromine substitution at the $\mathrm{R}_{1}$ position, the presence of methyl group in $\mathrm{R}_{2}$ may cause their different orientations in the active site and then the difference in inhibitory activity. The predicted binding mode of compound $8 \mathrm{f}$ shows that the $\mathrm{NH}$ proton of the amide group forms hydrogen bond interaction with the amide group of GIn350. The hydrogen bond belonging to the carbonyl oxygen of the amide group was not seen in this compound. Moreover, the $\mathrm{CH}$ imine group is forming a hydrogen contact with carboxyl oxygen of Asp349 and thus leads to a better fit of this compound in the enzyme's active pocket (Fig. $5 \mathrm{c}-\mathrm{d}$ ). The calculated GOLD Fitness Scores for compounds 8e (70.4927), 8I (65.7091), $8 \mathrm{f}$ (64.84.4) and 8n (61.1567) were in good agreement with those results obtained in in vitro assay.

\subsection{Molecular dynamic investigation}

Molecular dynamic simulation performed in order to understand the effect of the compound over the enzyme active site. For this purpose, the structural perturbations incurred by the most potent compound 
(8e) has been investigated through the study of the RMSD, RMSF and its effect on the active site environment in comparison to acarbose as a-glycosidase standard inhibitor and the apoenzyme.

Root mean square deviation (RMSD) of the enzymes' backbone was analyzed over 20 ns MD simulation in order to study the stability of the protein-ligand complex trajectories (Fig. 6). The RMSD value of the apo a-glycosidase depicts broad fluctuations throughout simulation time which is higher than the two enzyme complexes. The RMSD value increased after about $4 \mathrm{~ns}$ and steadily increased up to $16 \mathrm{~ns}$ and become more stable for the last $4 \mathrm{~ns}$ of simulation time with the value of $2.5 \AA$. The RMSD value of glycosidase complexed with acarbose was stable until $12 \mathrm{~ns}$ and slightly increased through the next $4 \mathrm{~ns}$ and become steady for the rest of the simulation time with the RMSD value of $2.1 \AA$. Although, the mentioned value of a-glycosidase complexed with compound $8 \mathrm{e}$ is the same as acarbose bounded state for the first $8 \mathrm{~ns}$ it is observed that compound $8 \mathrm{e}$ had higher RMSD than acarbose for its higher number of ring and flexibility which makes it more deviate from the initial structure for the next 8 ns and finally it decreased and stabilized for the last $2 \mathrm{~ns}$ with the same RMSD as acarbose bounded state $(2.1 \AA)$.

In summary, the RMSD value of the bounded state enzymes deviate from the initial structure of apoenzyme in the early part of the simulation and obviously decreased as a result of a-glycosidase structural rigidity. Thus, the structures at the last $2 \mathrm{~ns}$ of the MD equilibrium state used to investigate the structural specificity of the ligand-protein complexes.

The RMSF, which indicates the flexibility of protein structure, refers to the fluctuation of the Ca atom from its average position throughout the simulation time. Figure 7a compares the residue RMSF values of aglycosidase bound state and unbound state in which, the apoenzyme (yellow color line) had higher RMSF fluctuations compared to the glycosidase bound-states (green and red-colored lines). This observation occurs upon ligand binding to the enzyme, in which residues movement decrease as a result of nonbonding interaction between the ligand and the enzyme. In addition, the structural segments which are affected upon ligand binding have recognized and categorized into four apparent parts including; $\mathrm{B}$ domain loop (residues 139-149), the active site lid, A domain and B domain sides of the active site mouth. Comparing RMSF values shows that the residues of the B domain loop, 139-149, would have significantly lower RMSF value in glycosidase/ acarbose and compound 8e bound-state rather than apoenzyme (Fig. 7a and 7b). In contrast, the flexibility of the active site lid increased in enzyme boundstate and is more pronounced through acarbose binding. In order to investigate the reason for the mentioned observation, as noticed in Fig. 7b (glycosidase/ acarbose complex) acarbose interacted with several residues located into the $A$ and $B$ domain side of the active site mouth (the vertical green line). Although compound $8 \mathrm{e}$ interacted with the same regions, it formed fewer interaction with the residues of the A domain. So, it can be proposed that the more ligand interaction with $A$ and $B$ domain sides of the active site mouth, the higher the RMSF of the active site lid. Moreover, Fig. 7c and $2 d$ represent the organization of the a-glycosidase three main domains; $A, B$, and $C$ and the close-up representation of the active site mouth with the corresponding residues of $A$ and $B$ domain at both sides in which the active side lid and a back-wall helix situated at the front and the back of the mentioned mouth, respectively. Backing to the Fig. 7b, compound 8e provides higher interaction with the back-wall of the active site 
rather than acarbose. Based on the observed result of RMSF plot, although a-glycosidase/ acarbose complex with higher interaction at the entrance region loop covering the active site (310-315) have lower RMSF value than in a-glycosidase-8e complex, the other lid loop covering the active site consists of residues $230-236^{41}$ shows significantly lower RMSF value in a-glycosidase-8e complex rather than aglycosidase/ acarbose complex.

Finally, based on RMSF plot it can be proposed that compound 8e had more interaction over the B domain side and back-wall helix of the active site, while acarbose formed more interaction with the $A$ domain side of the a-glycosidase active site.

Figure $8 \mathrm{a}$ and $8 \mathrm{~b}$ represent the detailed orientation and interactions that occurred more than $30 \%$ of the simulation time during the equilibrated phase over a-glycosidase complexed with compound $8 \mathrm{e}$. The interaction analysis depicts compound 8e oriented vertically from the mouth to the bottom of the active site and stabilized the enzyme domains by interacting with Phe311, Tyr313, Arg312 from the A domain side and Phe158, Phe177 and His239 from the B domain side of the active site mouth (Fig. 8a). In addition, polar residues including; Asp214, Asp349 and Arg439 provide polar interactions with compound $8 \mathrm{e}$ at the depth part of the active site. In the same way, acarbose disposed vertically and formed nonbinding interactions with the Phe311, Asn241, Arg439, Asp68, His245, Asp349, Asp214 which belong to the domain A of the enzyme (Fig. 8c).

Comparing MD simulation of compound $8 \mathrm{e}$ and acarbose proposed the long-lasting non-binding interactions with Asp349, Asp214 and Arg439 have a significant role in inhibition activity of the mentioned compounds (Fig. 8b and 8d). Figure $8 \mathrm{a}$ and $8 \mathrm{~b}$ represent two important structural moieties in stabilizing compound $8 \mathrm{e}$ at the mouth of the active site. The first one is the benzofuran ring which interacts with Phe311 and Tyr313 through T-shape $\pi-\pi$ hydrophobic interactions for $90 \%$ and $55 \%$ of the simulation time and the next one, pyrazole ring which interacts with Arg312 through $\pi$-cation hydrophobic interaction for $96 \%$ of the simulation time. Along with the interactions which stabilized compound $8 \mathrm{e}$ in front of the A domain side of the active site entrance, the phenyl substituent interacts with Phe157 and His239 which faced at the B domain side of the entrance for about one-third of the simulation time. In addition, the hydrazide moiety can provide $\mathrm{H}$-bond interaction with Asp408 at the back part of the active site (previously known as the back wall side) for about $35 \%$ of simulation time. Finally, the nitrophenyl group as a polar moiety interacts with polar catalytic residues Arg439, Asp349 and Asp215 through ionbridge, $\mathrm{H}$-bond and water-mediated $\mathrm{H}$-bond interactions for a significant amount of simulation time that is similar to the behavior of the $\mathrm{NH} 2$ group in the acarbose (Fig. 8d). It is obvious from the MD study that $\mathrm{H}$-bond, hydrophobic interactions and ion-bridge interactions have a critical role in stabilizing compound $8 \mathrm{e}$ at different sides of the active site during the simulation time and cause a-glycosidase inhibition activity. This observation may propose the contribution to the higher a-glycosidase inhibition activity.

\section{Conclusion}


With aim of development of novel class of a-glucosidase inhibitors, new series of biphenyl pyrazolebenzofuran hybrids derivatives were designed, synthesized and evaluated for their a-glucosidase inhibition. All screened compounds displayed multifold enhanced inhibitory strength in the range of 40.6 $\pm 0.2-164.3 \pm 1.8 \mu \mathrm{M}$ when compared to acarbose $\left(\mathrm{IC}_{50}=750.0 \pm 10.0 \mu \mathrm{M}\right)$. Among them compound $8 \mathrm{e}$, having a nitro group in $\mathrm{R}_{1}$ position, was found to be the most potent inhibitor. This is approximately eighteen-fold more potent than the standard acarbose. Also, the kinetic analysis revealed that compound 8 compete with the substrate for binding to the binding site of the enzyme. Limited SAR studies indicated that the in vitro a-glucosidase inhibitory activity mainly depends upon the substituents on $\mathrm{R}_{1}$ and the nature of substituents at this position affected the efficacy of methyl group on $R_{2}$. Binding mode analysis showed that almost all structural features such as pyrazole ring, Phenyl groups attached to the pyrazole moiety, amide linkage and benzofuran scaffold are contributing to binding affinity through hydrogen bonding, hydrophobic and electrostatic interactions. In addition, MD simulations showed compound 8 e oriented vertically into the active site from mouth to the bottom and stabilized the enzyme domains by interacting with the interface of domain $A$ and domain $B$ and the back side of the active site while acarbose formed non-binding interaction with the residue belong to the domain $A$ of the enzyme. Moreover, carbonyl hydrazide linker, pyrazole and its related substituents provide such a strategic point with the ability to interact with various parts of the active site which has the binding and catalytic role for a-glycosidase activity.

Taken together, the above results suggest that newly synthesized hybrids could be promising hits for the further development of a-glucosidase inhibitors for the treatment of diabetes patients.

\section{Experimental}

All reagents and organic solvents were purchased from Sigma Chemical Co. (St. Louis, USA) and used without further purification. Thin-layer chromatography (TLC) was carried out on pre-coated silica gel aluminum plates (Merck silica gel 60, F254). Melting points of target compound 8a-o were measured on a Kofler hot stage apparatus and were uncorrected. ${ }^{1} \mathrm{H}$ NMR and ${ }^{13} \mathrm{C}$ NMR spectra were recorded on Bruker FT-500 spectrometer (Bruker, Rheinstetten, Germany) in DMSO- $\mathrm{d}_{6}$ with tetramethylsilane (TMS) as the internal standard. IR spectra were recorded on Nicolet Magna FTIR 550 spectrophotometer (resolution 2 $\mathrm{cm}^{-1}$ ) in $\mathrm{KBr}$ pellets. Elemental analysis was carried out with an Elemental Analyzer system $\mathrm{GmbH}$ VarioEL CHNS mode (Germany).

\subsection{General procedure for the preparation of 1,3- disubstituted-4-pyrazole carbaldehydes 4a-n}

To a solution of 4-substituted phenylhydrazine hydrochloride $2(20 \mathrm{mmol})$ in ethanol $(15 \mathrm{~mL})$, substituted acetophenone $1(20 \mathrm{mmol})$ and catalytic amounts of sulfuric acid was added and then reflux the mixture for 8-12 h. After reaction completion, the mixture was cooled to room temperature and poured on crushed ice to afford hydrazone intermediate $3 a-n$. The resulting solid was filtered and recrystallized from 
ethanol. A solution of hydrazone 3a-n $(20 \mathrm{mmol})$ in DMF $(5 \mathrm{~mL})$ was added drop-wise to an ice-cold solution of DMF $(15 \mathrm{~mL})$ and phosphorus oxychloride $(60 \mathrm{mmol})$ and the resulting mixture refluxed at $60-70^{\circ} \mathrm{C}$ for $5-8 \mathrm{~h}$. After the completion of the reaction, the reaction mixture allowed to cool, poured into ice-cold water and then neutralized with saturated aqueous sodium hydroxide solution. Further, the solid precipitated was filtered, washed with excess cold water and recrystallized from ethanol to afford aldehydes 4a-n.

\subsection{General procedure for the preparation of ethyl benzofuran-2-carboxylate 6}

A mixture of salicylaldehyde $(20 \mathrm{mmol})$, ethyl bromoacetate $(20 \mathrm{mmol})$ and $\mathrm{K}_{2} \mathrm{CO}_{3}(40 \mathrm{mmol})$ in acetonitrile $(10 \mathrm{~mL})$ heated under reflux for $4 \mathrm{~h}$. After completion of the reaction (monitored by TLC), the reaction mixture was allowed to cool to room temperature and poured into crushed ice. After extracting the product with ethyl acetate $(2 \times 25 \mathrm{~mL})$, the organic layer was washed using brine solution $(2 \times 20 \mathrm{~mL})$ and dried over anhydrous $\mathrm{MgSO}_{4}$. The solvent was evaporated under vacuum to afford the product as an oil.

\subsection{General procedure for the preparation of benzofuran-2- carbohydrazide 7}

benzofuran-2-carboxylate $6(20 \mathrm{mmol})$ and hydrazine hydrate $(30 \mathrm{mmol})$ in EtOH $(10 \mathrm{~mL})$ heat under reflux overnight. Upon cooling, the product precipitated was filtered, washed with cold water and recrystallized in methanol to afford the pure product.

\subsection{General procedure for the preparation of pyrazole- benzofuran hybrids $8 a-n$}

To a mixture of the appropriate pyrazole aldehydes $4(1 \mathrm{mmol})$ and catalytic amount of glacial acetic acid (3-4 drops) in absolute ethanol $(10 \mathrm{~mL})$, were added hydrazide $7(1.1 \mathrm{mmol})$ and refluxed for $12-18$ h. As the reaction was completed, the mixture was allowed to cool to room temperature, the precipitate was filtered off and crystallized from ethanol to give the pure final derivatives 8a-n.

\subsubsection{N'-((1,3-Diphenyl-1H-pyrazol-4- yl)methylene)benzofuran-2-carbohydrazide (8a)}

Creamish powder; yield: $86 \%, \mathrm{mp} 210-211^{\circ} \mathrm{C} . \mathrm{IR}\left(\mathrm{KBr}, \mathrm{cm}^{-1}\right)$ : 3345(N-H), $3080-2980(\mathrm{C}-\mathrm{H}), 1656(\mathrm{C}=0)$, 15615(C = N), 1435(C = C). ${ }^{1} \mathrm{H} \mathrm{NMR}\left(400 \mathrm{MHz}, \mathrm{DMSO}-d_{6}\right) \delta 12.22(\mathrm{~s}, 1 \mathrm{H}, \mathrm{NH}), 9.15$ (s, 1H, H - pyr), 8.79 (s, $1 \mathrm{H}, \mathrm{CH}=\mathrm{N}), 8.16(\mathrm{~d}, J=7.9 \mathrm{~Hz}, 2 \mathrm{H}, \mathrm{Ar}-\mathrm{H}), 7.88-7.79(\mathrm{~m}, 4 \mathrm{H}, \mathrm{Ar}-\mathrm{H}), 7.65(\mathrm{~m}, 7 \mathrm{H}, \mathrm{Ar}-\mathrm{H}), 7.49(\mathrm{~m}, 2 \mathrm{H}, \mathrm{Ar}-\mathrm{H})$. ${ }^{13} \mathrm{C}$ NMR (101 MHz, DMSO) $\delta 154.35,154.20,151.99,148.06,142.00,139.00,131.89,129.57,128.76$, $128.61,128.44,127.15,127.12,127.00,123.85,122.85,118.85,116.74,111.82,110.69$. Anal. Calcd for $\mathrm{C}_{25} \mathrm{H}_{18} \mathrm{~N}_{4} \mathrm{O}_{2}$ : C, 73.88; $\mathrm{H}, 4.46 ; \mathrm{N}, 13.78$. Found: $\mathrm{C}, 73.21 ; \mathrm{H}, 4.24 ; \mathrm{N}, 13.92$. 


\subsubsection{N'-((1-Phenyl-3-p-tolyl-1H-pyrazol-4- yl)methylene)benzofuran-2-carbohydrazide (8b)}

Creamish powder; yield: 81\%, mp 234-235 C. IR (KBr, cm $\left.{ }^{-1}\right): 3385(\mathrm{~N}-\mathrm{H}), 3010-2923(\mathrm{C}-\mathrm{H}), 1648(\mathrm{C}=0)$, 1555(C = N), 1450(C = C). ${ }^{1} \mathrm{H}$ NMR (400 MHz, DMSO-d $) \delta 12.20$ (s, 1H, NH), 9.13 (s, 1H, Hs-pyr), 8.77 (s, $1 \mathrm{H}, \mathrm{CH}=\mathrm{N}), 8.15$ (d, J=7.9 Hz, 2H, Ar-H), $7.93(\mathrm{~m}, J=7.7 \mathrm{~Hz}, 1 \mathrm{H}, \mathrm{Ar}-\mathrm{H}), 7.80-7.82(\mathrm{~m}, 2 \mathrm{H}, \mathrm{Ar}-\mathrm{H}), 7.76(\mathrm{~d}, J$ $=8.0 \mathrm{~Hz}, 2 \mathrm{H}, \mathrm{Ar}-\mathrm{H}), 7.63(\mathrm{~m}, 3 \mathrm{H}, \mathrm{Ar}-\mathrm{H}), 7.48(\mathrm{~m}, 4 \mathrm{H}, \mathrm{Ar}-\mathrm{H}), 2.52\left(\mathrm{~s}, 3 \mathrm{H}, \mathrm{CH}_{3}\right) .{ }^{13} \mathrm{C} \mathrm{NMR}(101 \mathrm{MHz}, \mathrm{DMSO}) \delta$ 154.34, 154.19, 152.04, 148.07, 142.14, 139.02, 138.07, 129.55, 129.31, 129.05, 128.33, 127.15, 127.02, 126.99, 126.93, 123.85, 122.84, 118.81, 116.64, 111.82, 110.67, 20.86. Anal. Calcd for $\mathrm{C}_{26} \mathrm{H}_{20} \mathrm{~N}_{4} \mathrm{O}_{2}: \mathrm{C}_{\text {, }}$ 74.27; H, 4.79; N, 13.33. Found: C, 74.83; H, 3.99; N, 13.73.

\subsubsection{N'-((3-(4-Methoxyphenyl)-1-phenyl-1H-pyrazol-4- yl)methylene)benzofuran-2-carbohydrazide (8c)}

White powder; yield: 78\%, mp 207-209 ${ }^{\circ} \mathrm{C} . \mathrm{IR}\left(\mathrm{KBr}, \mathrm{cm}^{-1}\right)$ : 3408(N-H), $3214-2980(\mathrm{C}-\mathrm{H}), 1670(\mathrm{C}=0)$, 1537(C = N), 1446(C = C). ${ }^{1} \mathrm{H}$ NMR (400 MHz, DMSO-d $) \delta 12.22$ (s, 1H, NH), $9.12\left(\mathrm{~s}, 1 \mathrm{H}, \mathrm{H}_{5}-\mathrm{pyr}\right), 8.77$ (s, $1 \mathrm{H}, \mathrm{CH}=\mathrm{N}), 8.15$ (d, J=8.0 Hz, 2H, Ar-H), 7.94 (d, J= 7.7 Hz, 1H, Ar-H), 7.81-7.83 (m, 4H, Ar-H), 7.68-7.60 (m, 3H, Ar-H), 7.49 (t, J= $7.4 \mathrm{~Hz}, 2 \mathrm{H}, \mathrm{Ar}-\mathrm{H}), 7.23$ (d, J=8.6 Hz, 2H, Ar-H), $3.96\left(\mathrm{~s}, 3 \mathrm{H}, \mathrm{OCH}_{3}\right) .{ }^{13} \mathrm{C} \mathrm{NMR}(101$ MHz, DMSO) $\delta 159.59,154.34,154.18,151.85,148.08,142.20,139.03,129.76,129.54,127.15,127.00$, $126.86,124.27,123.85,122.84,118.75,116.46,114.17,111.82,110.67,55.25$. Anal. Calcd for $\mathrm{C}_{26} \mathrm{H}_{20} \mathrm{~N}_{4} \mathrm{O}_{3}: \mathrm{C}, 71.55 ; \mathrm{H}, 4.62 ; \mathrm{N}, 12.84$. Found: $\mathrm{C}, 71.83 ; \mathrm{H}, 4.21 ; \mathrm{N}, 12.20$.

\subsection{4. (E)-N'-((3-(4-hydroxyphenyl)-1-phenyl-1 H-pyrazol-4- yl)methylene)benzofuran-2-carbohydrazide (8d)}

Creamish powder; yield: 81\%, mp 280-281 ㄷ․ IR $\left(\mathrm{KBr}, \mathrm{cm}^{-1}\right): 3506(\mathrm{~N}-\mathrm{H}), 2996-3195(\mathrm{C}-\mathrm{H}), 1646(\mathrm{C}=0)$,

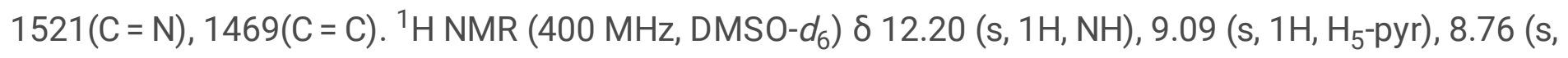
$1 \mathrm{H}, \mathrm{CH}=\mathrm{N}),[8.14(\mathrm{~d}, J=7.8 \mathrm{~Hz}, 2 \mathrm{H}), 7.93(\mathrm{~d}, J=7.8 \mathrm{~Hz}, 1 \mathrm{H}), 7.81-7.83(\mathrm{~m}, 2 \mathrm{H}), 7.46-7.70(\mathrm{~m}, 6 \mathrm{H}), 7.46-$ $7.50(\mathrm{~m}, 2 \mathrm{H}), 7.05$ (d, J=8.5 Hz, 2H)] (15H, Ar-H and OH). ${ }^{13} \mathrm{C}$ NMR (101 MHz, DMSO) $\delta ~ 157.97,154.34$, $154.18,152.25,148.09,142.37,139.06,129.75,129.53,127.13,126.99,126.82,126.77,123.84,122.84$, 122.61, 118.69, 116.30, 115.51, 111.82, 110.63. Anal. Calcd for $\mathrm{C}_{25} \mathrm{H}_{18} \mathrm{~N}_{4} \mathrm{O}_{3}$ : C, 71.08; $\mathrm{H}, 4.29 ; \mathrm{N}, 13.26$. Found: C, 71.68; H, 4.49; N, 13.76.

\subsubsection{N'-((3-(4-Nitrophenyl)-1-phenyl-1H-pyrazol-4- yl)methylene)benzofuran-2-carbohydrazide (8e)}

Yellow powder; yield: 73\%, mp 241-243 ${ }^{\circ} \mathrm{C} . \mathrm{IR}\left(\mathrm{KBr}, \mathrm{cm}^{-1}\right): 3105(\mathrm{~N}-\mathrm{H}), 2907(\mathrm{C}-\mathrm{H}), 1669(\mathrm{C}=$ O), $1552(\mathrm{C}=$ $\mathrm{N}), 1444(\mathrm{C}=\mathrm{C}) .{ }^{1} \mathrm{H}$ NMR $\left(400 \mathrm{MHz}, \mathrm{DMSO}-d_{6}\right) \delta 12.31(\mathrm{~s}, 1 \mathrm{H}, \mathrm{NH}), 9.21\left(\mathrm{~s}, 1 \mathrm{H}, \mathrm{H}_{5}-\mathrm{pyr}\right), 8.82(\mathrm{~s}, 1 \mathrm{H}, \mathrm{CH}=$ $\mathrm{N})$, 8.39-8.50 (m, 2H, Ar-H), 8.22-8.05 (m, 3H, Ar-H), 7.93 (d, J= 7.7 Hz, 1H, Ar-H), 7.89-7.75 (m, 2H, Ar-H),

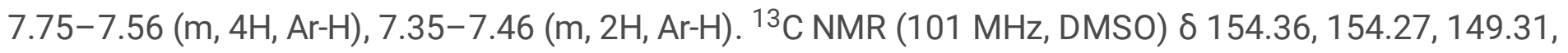


$147.98,147.15,141.28,138.77,138.41,129.61,129.50,128.55,127.37,127.22,126.98,123.87,123.78$, $123.53,122.88,119.00,118.76,117.52,111.82,110.90$. Anal. Calcd for $\mathrm{C}_{25} \mathrm{H}_{17} \mathrm{~N}_{5} \mathrm{O}_{4}: \mathrm{C}, 66.51 ; \mathrm{H}, 3.80 ; \mathrm{N}$, 15.51. Found: $\mathrm{C}, 65.83 ; \mathrm{H}, 3.12 ; \mathrm{N}, 14.93$.

\subsubsection{N'-((3-(4-Bromophenyl)-1-phenyl-1H-pyrazol-4- yl)methylene)benzofuran-2-carbohydrazide (8f)}

White powder; yield: $88 \%, \mathrm{mp} 243-245^{\circ} \mathrm{C}$. IR $\left(\mathrm{KBr}, \mathrm{cm}^{-1}\right)$ : 3430(N-H), 2845-3165 (C-H), 1655(C = 0),

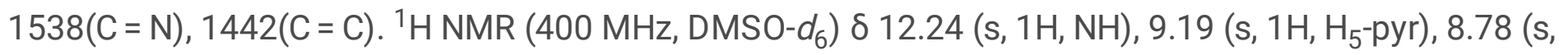
$1 \mathrm{H}, \mathrm{CH}=\mathrm{N}), 8.17(\mathrm{~d}, J=7.9 \mathrm{~Hz}, 2 \mathrm{H}, \mathrm{Ar}-\mathrm{H}), 7.95(\mathrm{~d}, J=7.7 \mathrm{~Hz}, 1 \mathrm{H}, \mathrm{Ar}-\mathrm{H}), 7.91-7.81(\mathrm{~m}, 6 \mathrm{H}, \mathrm{Ar}-\mathrm{H}), 7.82-7.96$ $(\mathrm{m}, 3 \mathrm{H}, \mathrm{Ar}-\mathrm{H}), 7.48-7.54$ (m, 2H, Ar-H). ${ }^{13} \mathrm{C}$ NMR (101 MHz, DMSO) $\delta 154.35,154.20,150.69,148.03$, $141.72,138.91,131.66,131.12,130.49,129.59,127.69,127.19,127.12,126.98,123.87,122.87,122.07$, 118.89, 116.83, 111.83, 110.77. Anal. Calcd for $\mathrm{C}_{25} \mathrm{H}_{17} \mathrm{BrN}_{4} \mathrm{O}_{2}: \mathrm{C}, 61.87 ; \mathrm{H}, 3.53 ; \mathrm{N}, 11.54$. Found: $\mathrm{C}, 61.16$; $H, 3.21 ; N, 12.04$

\subsubsection{N'-((3-(4-Chlorophenyl)-1-phenyl-1H-pyrazol-4- yl)methylene)benzofuran-2-carbohydrazide $(8 \mathrm{~g})$}

Creamish powder; yield: 81\%, mp 241-243 ${ }^{\circ} \mathrm{C} . \mathrm{IR}\left(\mathrm{KBr}, \mathrm{cm}^{-1}\right)$ : $3491(\mathrm{~N}-\mathrm{H}), 2945-3223(\mathrm{C}-\mathrm{H}), 1652(\mathrm{C}=\mathrm{O})$, 1553 $(\mathrm{C}=\mathrm{N}), 1503(\mathrm{C}=\mathrm{C}) .{ }^{1} \mathrm{H}$ NMR $\left(400 \mathrm{MHz}, \mathrm{DMSO}-\mathrm{d}_{6}\right) \delta 12.26(\mathrm{~s}, 1 \mathrm{H}, \mathrm{NH}), 9.17\left(\mathrm{~s}, 1 \mathrm{H}, \mathrm{H}_{5}\right.$-pyr), $8.78(\mathrm{~s}$, $1 \mathrm{H}, \mathrm{CH}=\mathrm{N}), 8.16(\mathrm{~d}, J=7.9 \mathrm{~Hz}, 2 \mathrm{H}, \mathrm{Ar}-\mathrm{H}), 7.92-7.95(\mathrm{~m}, 3 \mathrm{H}, \mathrm{Ar}-\mathrm{H}), 7.85-7.79(\mathrm{~m}, 2 \mathrm{H}, \mathrm{Ar}-\mathrm{H}), 7.73(\mathrm{~d}, J=8.4$ $\mathrm{Hz}, 2 \mathrm{H}), 7.66$ (t, J= 8.0 Hz, 3H, Ar-H), 7.47-7.52 (m, 2H, Ar-H). ${ }^{13} \mathrm{C}$ NMR (101 MHz, DMSO) $\delta$ 154.34, $150.59,148.24,141.66,138.91,133.39,130.79,130.19,129.58,128.74,127.63,127.11,127.01,123.83$, $122.82,118.86,116.90,111.80,110.64$. Anal. Calcd for $\mathrm{C}_{25} \mathrm{H}_{17} \mathrm{ClN}_{4} \mathrm{O}_{2}: \mathrm{C}, 68.11 ; \mathrm{H}, 3.89 ; \mathrm{N}, 12.71$. Found: C, 68.53; H, 3.16; N, 12.52 .

\subsubsection{N'-((3-(4-Fluorophenyl)-1-phenyl-1H-pyrazol-4- yl)methylene)benzofuran-2-carbohydrazide (8h)}

White powder; yield: 84\%, mp 253-254 ${ }^{\circ} \mathrm{C}$. IR $\left(\mathrm{KBr}, \mathrm{cm}^{-1}\right)$ : $3500(\mathrm{~N}-\mathrm{H}), 2926-3093(\mathrm{C}-\mathrm{H}), 1661(\mathrm{C}=0)$, 1553(C= N), 1441 (C = C). ${ }^{1} \mathrm{H}$ NMR (400 MHz, DMSO- $\left.d_{6}\right) \delta 12.22(\mathrm{~s}, 1 \mathrm{H}, \mathrm{NH}), 9.15\left(\mathrm{~s}, 1 \mathrm{H}, \mathrm{H}_{5}\right.$-pyr), $8.76(\mathrm{~s}$, $1 \mathrm{H}, \mathrm{CH}=\mathrm{N}), 8.15(\mathrm{~d}, J=7.9 \mathrm{~Hz}, 2 \mathrm{H}, \mathrm{Ar}-\mathrm{H}), 7.92-7.96(\mathrm{~m}, 3 \mathrm{H}, \mathrm{Ar}-\mathrm{H}), 7.80-7.82(\mathrm{~m}, 2 \mathrm{H}), 7.60-7.67(\mathrm{~m}, 3 \mathrm{H})$, 7.53-7.46 (m, 4H). ${ }^{13} \mathrm{C}$ NMR (101 MHz, DMSO) $\delta 163.58,161.14,154.34,154.20,150.95,148.04,141.82$, 138.94, 130.65, 130.57, 129.57, 128.42, 127.41, 127.18, 127.03, 126.98, 123.86, 122.86, 118.84, 116.69, 115.76, 115.55, 111.82, 110.74. Anal. Calcd for $\mathrm{C}_{25} \mathrm{H}_{17} \mathrm{FN}_{4} \mathrm{O}_{2}: \mathrm{C}, 70.75 ; \mathrm{H}, 4.04 ; \mathrm{N}, 13.20$. Found: $\mathrm{C}, 70.26$; $\mathrm{H}, 4.34 ; \mathrm{N}, 13.61$.

\subsubsection{N'-((1-Phenyl-3-(4-(trifluoromethyl)phenyl)-1H- pyrazol-4-yl)methylene)benzofuran-2-carbohydrazide (8i)}


White powder; yield: $78 \%, \mathrm{mp} 217-218^{\circ} \mathrm{C} . \mathrm{IR}\left(\mathrm{KBr}, \mathrm{cm}^{-1}\right)$ : $337(\mathrm{~N}-\mathrm{H}), 2909-3050(\mathrm{C}-\mathrm{H}), 1665(\mathrm{C}=\mathrm{0})$, 1555(C = N), 1442(C=C). ${ }^{1} \mathrm{H}$ NMR (400 MHz, DMSO-d $\left.)_{6}\right) \delta 12.25(\mathrm{~s}, 1 \mathrm{H}, \mathrm{NH}), 9.23\left(\mathrm{~s}, 1 \mathrm{H}, \mathrm{H}_{5}\right.$-pyr), $8.80(\mathrm{~s}$, $1 \mathrm{H}, \mathrm{CH}=\mathrm{N}), 8.21-8.13(\mathrm{~m}, 4 \mathrm{H}, \mathrm{Ar}-\mathrm{H}), 8.04(\mathrm{~d}, J=8.2 \mathrm{~Hz}, 2 \mathrm{H}, \mathrm{Ar}-\mathrm{H}), 7.94(\mathrm{~d}, J=7.8 \mathrm{~Hz}, 1 \mathrm{H}, \mathrm{Ar}-\mathrm{H}), 7.81-7.84$ (m, 2H, Ar-H), 7.61-7.70 (m, 3H, Ar-H), 7.47-7.54 (m, 2H, Ar-H). ${ }^{13} \mathrm{C}$ NMR (101 MHz, DMSO) $\delta 154.35$, 154.21, 150.33, 148.00, 141.53, 138.86, 135.96, 129.62, 129.24, 128.94, 128.62, 127.94, 127.26, 127.21, $126.98,125.59,125.55,123.88,122.87,118.96,117.15,111.82,110.83$. Anal. Calcd for $\mathrm{C}_{26} \mathrm{H}_{17} \mathrm{~F}_{3} \mathrm{~N}_{4} \mathrm{O}_{2}: \mathrm{C}$, $65.82 ; \mathrm{H}, 3.61 ; \mathrm{N}, 11.81$. Found: $\mathrm{C}, 65.21 ; \mathrm{H}, 3.32 ; \mathrm{N}, 11.10$.

\subsubsection{N'-((3-Phenyl-1-p-tolyl-1H-pyrazol-4- yl)methylene)benzofuran-2-carbohydrazide (8j)}

White powder; yield: $81 \%$, mp 255-256 ${ }^{\circ} \mathrm{C}$. IR $\left(\mathrm{KBr}, \mathrm{cm}^{-1}\right)$ : 3420(N-H), 2917-3050 (C-H), 1646(C = 0), 1537 $(\mathrm{C}=\mathrm{N}), 1442(\mathrm{C}=\mathrm{C}) .{ }^{1} \mathrm{H}$ NMR $\left(400 \mathrm{MHz}, \mathrm{DMSO}-d_{6}\right) \delta 12.20(\mathrm{~s}, 1 \mathrm{H}, \mathrm{NH}), 9.08\left(\mathrm{~s}, 1 \mathrm{H}, \mathrm{H}_{5}\right.$-pyr), $8.77(\mathrm{~s}$, $1 \mathrm{H}, \mathrm{CH}=\mathrm{N}), 8.02(\mathrm{~d}, J=8.4 \mathrm{~Hz}, 2 \mathrm{H}, \mathrm{Ar}-\mathrm{H}), 7.87-7.78(\mathrm{~m}, 4 \mathrm{H}, \mathrm{Ar}-\mathrm{H}), 7.69-7.56(\mathrm{~m}, 5 \mathrm{H}, \mathrm{Ar}-\mathrm{H}), 7.43-7.49(\mathrm{~m}$, $3 \mathrm{H}, \mathrm{Ar}-\mathrm{H}), 2.46$ (s, 3H, $\left.\mathrm{CH}_{3}\right) .{ }^{13} \mathrm{C}$ NMR (101 MHz, DMSO) $\delta 154.34,154.19,151.75,148.08,142.06,136.80$, 136.42, 131.96, 129.93, 128.74, 128.54, 128.42, 127.14, 126.99, 126.90, 123.84, 122.84, 118.77, 116.51, 111.81, 110.66, 20.47. Anal. Calcd for $\mathrm{C}_{26} \mathrm{H}_{20} \mathrm{~N}_{4} \mathrm{O}_{2}$ : C, 74.27; $\mathrm{H}, 4.79 ; \mathrm{N}, 13.33$. Found: $\mathrm{C}, 74.66 ; \mathrm{H}, 4.32 ; \mathrm{N}$, 13.91.

\subsubsection{N'-((1,3-Dip-tolyl-1H-pyrazol-4- yl)methylene)benzofuran-2-carbohydrazide (8k)}

White powder; yield: $83 \%$, mp 259-261 ${ }^{\circ} \mathrm{C}$. IR $\left(\mathrm{KBr}, \mathrm{cm}^{-1}\right)$ : 3450(N-H), 2945-3065 (C-H), 1665(C= 0), $1580(\mathrm{C}=\mathrm{N}), 1455(\mathrm{C}=\mathrm{C}) .{ }^{1} \mathrm{H}$ NMR $\left(400 \mathrm{MHz}, \mathrm{DMSO}-d_{6}\right) \delta 12.18(\mathrm{~s}, 1 \mathrm{H}, \mathrm{NH}), 9.05\left(\mathrm{~s}, 1 \mathrm{H}, \mathrm{H}_{5}\right.$-pyr), $8.76(\mathrm{~s}$, $1 \mathrm{H}, \mathrm{CH}=\mathrm{N}), 8.01(\mathrm{~d}, J=8.2 \mathrm{~Hz}, 2 \mathrm{H}, \mathrm{Ar}-\mathrm{H}), 7.91(\mathrm{~d}, J=7.7 \mathrm{~Hz}, 1 \mathrm{H}, \mathrm{Ar}-\mathrm{H}), 7.79-7.81(\mathrm{~m}, 2 \mathrm{H}, \mathrm{Ar}-\mathrm{H}), 7.74(\mathrm{~d}, J$ $=7.8 \mathrm{~Hz}, 2 \mathrm{H}, \mathrm{Ar}-\mathrm{H}), 7.60(\mathrm{t}, J=7.7 \mathrm{~Hz}, 1 \mathrm{H}, \mathrm{Ar}-\mathrm{H}), 7.48-7.38(\mathrm{~m}, 5 \mathrm{H}, \mathrm{Ar}-\mathrm{H}), 2.50\left(\mathrm{~s}, 3 \mathrm{H}, \mathrm{CH}_{3}\right), 2.46(\mathrm{~s}, 3 \mathrm{H}$, $\left.\mathrm{CH}_{3}\right) .{ }^{13} \mathrm{C}$ NMR $(101 \mathrm{MHz}$, DMSO) $\delta 154.34,154.18,151.80,148.09,142.20,137.98,136.82,136.33$, $129.92,129.56,129.28,129.12,128.75,128.30,127.13,126.99,126.80,123.84,122.83,118.72,116.41$, 111.81, 110.64, 20.85, 20.46. Anal. Calcd for $\mathrm{C}_{27} \mathrm{H}_{22} \mathrm{~N}_{4} \mathrm{O}_{2}$ : C, 74.64; $\mathrm{H}, 5.10 ; \mathrm{N}, 12.89$. Found: $\mathrm{C}, 74.25 ; \mathrm{H}$, $5.42 ; \mathrm{N}, 12.24$.

\subsubsection{N'-((3-(4-Methoxyphenyl)-1-p-tolyl-1H-pyrazol-4- yl)methylene)benzofuran-2-carbohydrazide (8I)}

White powder; yield: $82 \%, \mathrm{mp} 230-232^{\circ} \mathrm{C}$. IR $\left(\mathrm{KBr}, \mathrm{cm}^{-1}\right)$ : 3442(N-H), 2890-3120 (C-H), 1670(C = 0), $1540(\mathrm{C}=\mathrm{N}), 1450(\mathrm{C}=\mathrm{C}) .{ }^{1} \mathrm{H}$ NMR $\left(400 \mathrm{MHz}, \mathrm{DMSO}-d_{6}\right) \delta 12.20(\mathrm{~s}, 1 \mathrm{H}, \mathrm{NH}), 9.06\left(\mathrm{~s}, 1 \mathrm{H}, \mathrm{H}_{5}\right.$-pyr), 8.76 (s, $1 \mathrm{H}, \mathrm{CH}=\mathrm{N}), 8.03(\mathrm{~d}, J=8.4 \mathrm{~Hz}, 2 \mathrm{H}, \mathrm{Ar}-\mathrm{H}), 7.94(\mathrm{~d}, J=7.7 \mathrm{~Hz}, 1 \mathrm{H}, \mathrm{Ar}-\mathrm{H}), 7.80-7.83(\mathrm{~m}, 4 \mathrm{H}, \mathrm{Ar}-\mathrm{H}), 7.62(\mathrm{t}, J=$ $7.5 \mathrm{~Hz}, 1 \mathrm{H}, \mathrm{Ar}-\mathrm{H}), 7.50-7.43(\mathrm{~m}, 3 \mathrm{H}, \mathrm{Ar}-\mathrm{H}), 7.23$ (d, J=8.7 Hz, 2H, Ar-H), 3.96 (s, 3H, OCH $)_{3}, 2.48(\mathrm{~s}, 3 \mathrm{H}$, 
$\left.\mathrm{CH}_{3}\right) .{ }^{13} \mathrm{C}$ NMR $(101 \mathrm{MHz}$, DMSO) $\delta 159.55,154.34,154.16,151.62,148.10,142.25,136.83,136.26$, 129.92, 129.73, 127.14, 126.99, 126.80, 124.35, 123.85, 122.84, 118.68, 116.23, 114.15, 111.82, 110.63, 55.25, 20.47. Anal. Calcd for $\mathrm{C}_{27} \mathrm{H}_{22} \mathrm{~N}_{4} \mathrm{O}_{3}: \mathrm{C}, 71.99 ; \mathrm{H}, 4.92 ; \mathrm{N}, 12.44$. Found: $\mathrm{C}, 71.43 ; \mathrm{H}, 4.36 ; \mathrm{N}, 12.72$.

\subsubsection{N'-((3-(4-Hydroxyphenyl)-1-p-tolyl-1H-pyrazol-4- yl)methylene)benzofuran-2-carbohydrazide (8m)}

Creamish powder; yield: 82\%, mp 293-295 ${ }^{\circ} \mathrm{C} . \mathrm{IR}\left(\mathrm{KBr}, \mathrm{cm}^{-1}\right)$ : $3460(\mathrm{~N}-\mathrm{H}), 2990-3165(\mathrm{C}-\mathrm{H}), 1666(\mathrm{C}=0)$, 1540 $(\mathrm{C}=\mathrm{N}), 1430(\mathrm{C}=\mathrm{C}) .{ }^{1} \mathrm{H}$ NMR $\left.(400 \mathrm{MHz} \text {, DMSO-d })_{6}\right) \delta 12.19(\mathrm{~s}, 1 \mathrm{H}, \mathrm{NH}), 9.02\left(\mathrm{~s}, 1 \mathrm{H}, \mathrm{H}_{5}\right.$-pyr), $8.75(\mathrm{~s}$, $1 \mathrm{H}, \mathrm{CH}=\mathrm{N}),[8.00(\mathrm{~d}, J=8.4 \mathrm{~Hz}, 2 \mathrm{H}), 7.92(\mathrm{~d}, J=7.6 \mathrm{~Hz}, 1 \mathrm{H}), 7.80-7.82(\mathrm{~m}, 2 \mathrm{H}), 7.59-7.68(\mathrm{~m}, 4 \mathrm{H}), 7.49-$ $7.40(\mathrm{~m}, 3 \mathrm{H}), 7.04(\mathrm{~d}, J=8.5 \mathrm{~Hz}, 2 \mathrm{H})](14 \mathrm{H}, \mathrm{Ar}-\mathrm{H}$ and $\mathrm{OH}), 2.46\left(\mathrm{~s}, 3 \mathrm{H}, \mathrm{CH}_{3}\right) \cdot{ }^{13} \mathrm{C} \mathrm{NMR}(101 \mathrm{MHz}, \mathrm{DMSO}) \delta$ $157.92,154.33,154.16,152.03,148.10,142.42,136.86,136.16,129.90,129.72,127.12,126.99,126.61$, $123.84,122.83,122.68,118.62,116.07,115.50,111.82,110.61,20.46$. Anal. Calcd for $\mathrm{C}_{26} \mathrm{H}_{20} \mathrm{~N}_{4} \mathrm{O}_{3}: \mathrm{C}$, 71.55; $\mathrm{H}, 4.62 ; \mathrm{N}, 12.84$. Found: $\mathrm{C}, 71.10 ; \mathrm{H}, 4.15 ; \mathrm{N}, 12.28$.

\subsubsection{N'-((3-(4-Bromophenyl)-1-p-tolyl-1H-pyrazol-4- yl)methylene)benzofuran-2-carbohydrazide (8n)}

White powder; yield: $75 \%, \mathrm{mp} 258-259^{\circ} \mathrm{C}$. IR $\left(\mathrm{KBr}, \mathrm{cm}^{-1}\right)$ : 3425(N-H), 2898-3098 (C-H), 1666(C = 0), 1535(C = N), 1450(C = C). ${ }^{1} \mathrm{H}$ NMR (400 MHz, DMSO- $\left.d_{6}\right) \delta 12.19(\mathrm{~s}, 1 \mathrm{H}, \mathrm{NH}), 9.10\left(\mathrm{~s}, 1 \mathrm{H}, \mathrm{H}_{5}\right.$-pyr), 8.75 (s, $1 \mathrm{H}, \mathrm{CH}=\mathrm{N}), 8.02(\mathrm{~d}, J=8.3 \mathrm{~Hz}, 2 \mathrm{H}, \mathrm{Ar}-\mathrm{H}), 7.92(\mathrm{~d}, J=7.7 \mathrm{~Hz}, 1 \mathrm{H}, \mathrm{Ar}-\mathrm{H}), 7.82-7.85(\mathrm{~m}, 5 \mathrm{H}, \mathrm{Ar}-\mathrm{H}), 7.61(\mathrm{t}, J=$

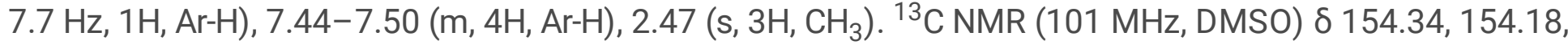
$150.45,148.04,141.77,136.71,136.55,131.64,131.19,130.45,129.95,127.47,127.18,126.98,123.87$, $122.86,121.99,118.80,116.61,111.82,110.75,20.47$. Anal. Calcd for $\mathrm{C}_{26} \mathrm{H}_{19} \mathrm{BrN}_{4} \mathrm{O}_{2}: \mathrm{C}, 62.54 ; \mathrm{H}, 3.84 ; \mathrm{N}$, 11.22. Found: $\mathrm{C}, 62.91 ; \mathrm{H}, 3.52 ; \mathrm{N}, 11.76$.

\subsubsection{N'-((3-(4-Chlorophenyl)-1-p-tolyl-1H-pyrazol-4- yl)methylene)benzofuran-2-carbohydrazide (80)}

White powder; yield: 83\%, mp 248-249 ${ }^{\circ} \mathrm{C} . \mathrm{IR}\left(\mathrm{KBr}, \mathrm{cm}^{-1}\right)$ : 3435(N-H), 2925-3050 (C-H), 1675(C = 0),

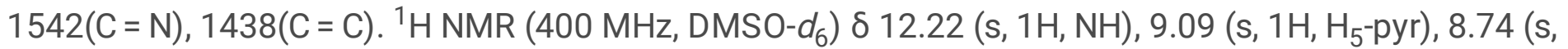
$1 \mathrm{H}, \mathrm{CH}=\mathrm{N}), 8.02(\mathrm{~d}, J=8.4 \mathrm{~Hz}, 2 \mathrm{H}, \mathrm{Ar}-\mathrm{H}), 7.90-7.94(\mathrm{~m}, 3 \mathrm{H}, \mathrm{Ar}-\mathrm{H}), 7.82-7.76(\mathrm{~m}, 2 \mathrm{H}, \mathrm{Ar}-\mathrm{H}), 7.72(\mathrm{~d}, J=8.4$ $\mathrm{Hz}, 2 \mathrm{H}, \mathrm{Ar}-\mathrm{H}), 7.63-7.57(\mathrm{~m}, 1 \mathrm{H}, \mathrm{Ar}-\mathrm{H}), 7.45-7.49(\mathrm{~m}, 3 \mathrm{H}, \mathrm{Ar}-\mathrm{H}), 2.48\left(\mathrm{~s}, 3 \mathrm{H}, \mathrm{CH}_{3}\right) .{ }^{13} \mathrm{C}$ NMR $(101 \mathrm{MHz}$, DMSO) $\delta 154.30,150.24,141.39,136.74,136.47,133.26,130.93,130.11,129.95,128.71,127.30,127.15$, $126.82,123.70,122.65,118.74,116.96,111.74,110.10,20.47$. Anal. Calcd for $\mathrm{C}_{26} \mathrm{H}_{19} \mathrm{ClN}_{4} \mathrm{O}_{2}: \mathrm{C}, 68.65 ; \mathrm{H}$, $4.21 ; \mathrm{N}, 12.32$. Found: $\mathrm{C}, 68.99 ; \mathrm{H}, 4.53 ; \mathrm{N}, 12.81$. 


\subsection{In vitro a-glucosidase inhibition assay}

Stock solutions of the test compounds and acarbose were prepared in DMSO and eventually diluted with phosphate buffer saline to attain the desired concentration. A mixture containing various concentrations of test compound and enzyme (Saccharomyces cerevisiae, EC3.2.1.20, 0.2 U/mL) in phosphate buffer saline was added in the 96 -well plate and incubated at $37^{\circ} \mathrm{C}$ for $10 \mathrm{~min}$. Then, the enzyme-catalyzed reaction was commenced by the addition of p-nitrophenyl-a-glucopyranoside as substrate $(25 \mu \mathrm{L}, 4 \mathrm{mM})$ and the absorbance was measured spectrophotometrically at $400 \mathrm{~nm}$ after $20 \mathrm{~min}$ incubation at $37^{\circ} \mathrm{C}$. DMSO (10\% final concentration) and acarbose were used as the control and standard inhibitor, respectively. The percentage of enzyme inhibition for each entry was calculated using the following formula:

$\%$ Inhibition $=[($ Abs control - Abs sample $) /$ Abs control $] \times 100$.

The concentrations of the compounds that inhibited $50 \%$ of $\alpha$-glucosidase activity ( $\left(\mathrm{C}_{50}\right.$ values) were calculated from non-linear regression curve using the Logit method.

\subsection{Kinetic study}

The kinetics of enzyme inhibition was performed according to the reaction conditions in 2.5 by preparing a series of test solutions in which the concentration of the substrate (PNPG) was varied (2-10 mM) in the absence and presence of compound $8 \mathrm{e}$ at different concentrations $(0,10,25$, and $40 \mu \mathrm{M})$. A LineweaverBurk plot was generated to identify the type of inhibition and the Michaelis-Menten constant $\left(K_{m}\right)$ value was determined from the plot between reciprocal of the substrate concentration (1/[S]) and reciprocal of enzyme rate $(1 / \mathrm{V})$ over various inhibitor concentrations. Experimental inhibitor constant $\left(K_{i}\right)$ value was constructed by secondary plots of the inhibitor concentration [l] versus $K_{\mathrm{m}}$.

\subsection{Homology modeling and docking study}

The primary sequence of Saccharomyces cerevisiae a-glucosidase downloaded from UniProtKB database (Uni- ProtKB, http://www.uniprot.org/) with accession number P53341. Hence, a search was executed to identify a protein with a high sequence similarity using NCBI BLAST server (https:// blast.ncbi.nlm.nih.gov/Blast.cgi). The crystallographic structure of Saccharomyces cerevisiae (PDB ID: 3A4A) was chosen as a template and subjected to sequence alignment using Align sequence to template protocol in Discovery Studio 4.1 (Accelrys, San Diego, CA) (DS). The 3D structure of a-glucosidase for S cerevisiae was predicted using the Build Homology Models protocol implemented in DS software. The number of models was set to 10 , and the optimization level was changed to high. DOPE score and profile3D for preliminary evaluation of developed model were carried out using verify protein protocol in DS. Ramachandran plot with PROCHECK program (http://servicesn.mbi.ucla.edu/PROCHECK) was also applied to verify the quality of the obtained homology model ${ }^{42,43}$. With the modeled structure, the docking of selected compounds was carried out. 
The predicted model was subjected to protein preparation using the prepare protein protocol in DS software. In this step, complex was typed with CHARMm force field, hydrogen atoms were added, all water molecules were removed and $\mathrm{pH}$ of protein was adjusted to almost neutral, 7.4. The 3D structure of the most active compounds $8 \mathrm{e}, 8 \mathrm{l}, 8 \mathrm{f}$ and $8 \mathrm{n}$ were built using the ChemDraw program and then were transferred into DS. Ligand structures were typed with CHARMm force field and partial charges were calculated by Momany-Rone option. Subsequently, resulting structures were minimized with Smart Minimizer which performs 1000 steps of steepest descent with a RMS gradient tolerance of 3 , followed by conjugate gradient minimization. Molecular docking approach have been carried out using genetic algorithm based docking program (GOLD) which considers complete flexibility of side chains of amino acids at the active site. $A 9 A^{\circ}$ radius sphere was defined as a docking pocket. Acarbose and most potent compounds were docked into the active site of the protein and generated binding modes of ligands were ranked based on GOLD score fitness function. A top-score binding pose was selected for analyzing the interactions between the enzyme and the inhibitors using DS Visualizer ${ }^{44}$.

\subsection{Molecular dynamic simulation}

Molecular dynamic (MD) simulation of this study was performed by using the Desmond v5.3 module implemented in Maestro interface (from Schrödinger 2018-4 suite) ${ }^{45}$. The appropriate pose for MD simulation procedure of the compounds was achieved by the docking method.

In order to build the system for MD simulation, the protein-ligand complexes were solvated with SPC explicit water molecules and placed in the center of an orthorhombic box of appropriate size in the Periodic Boundary Condition. Sufficient counter-ions and a $0.15 \mathrm{M}$ solution of $\mathrm{NaCl}$ were also utilized to neutralize the system and to simulate the real cellular ionic concentrations, respectively. The MD protocol involved minimization, pre-production, and finally production MD simulation steps. In the minimization procedure, the entire system was allowed to relax for 2500 steps by the steepest descent approach. Then the temperature of the system was raised from 0 to $300 \mathrm{~K}$ with a small force constant on the enzyme in order to restrict any drastic changes. MD simulations were performed via NPT (constant number of atoms, constant pressure i.e. 1.01325 bar and constant temperature i.e. $300 \mathrm{~K}$ ) ensemble. The NoseHoover chain method was used as the default thermostat with $1.0 \mathrm{ps}$ interval and Martyna-Tobias-Klein as the default barostat with $2.0 \mathrm{ps}$ interval by applying isotropic coupling style. Long-range electrostatic forces were calculated based on Particle-mesh-based Ewald approach with the he cut-off radius for columbic forces set to $9.0 \AA$ A. Finally, the system subjected to produce MD simulations for 20 ns for protein-ligand complex. During the simulation every 1000 ps of the actual frame was stored. The dynamic behavior and structural changes of the systems were analyzed by the calculation of the root mean square deviation (RMSD) and RMSF. Subsequently, the energy-minimized structure calculated from the equilibrated trajectory system was evaluated for investigation of each ligand-protein complex interaction.

\subsection{Prime MM-GBSA}


The ligand binding energies $\left(\Delta \mathrm{G}_{\text {Bind }}\right)$ were calculated for compound 80 and acarbose using Molecular mechanics/generalized born surface area (MMGBSA) modules (Schrödinger LLC 2018) (75) based on the following equation;

$\Delta \mathrm{G}$ Bind $=\mathrm{E}_{\text {Complex }}-\left[\mathrm{E}_{\text {Receptor }}+\mathrm{E}_{\text {Ligand }}\right]$

where $\triangle \mathrm{G}$ Bind is the calculated relative free energy which includes both ligand and receptor strain energy. $E_{\text {Complex }}$ is the MM-GBSA energy of the minimized complex, and $E_{\text {Ligand }}$ is the MM-GBSA energy of the ligand after removing it from the complex and allowing it to relax. $E_{\text {Receptor }}$ is the MM-GBSA energy of relaxed protein after separating it from the ligand. The MM-GBSA calculation was performed based on the clustering method for energy calculation.

\section{Declarations}

\section{Competing interests}

The author(s) declare no competing interests.

\section{References}

1. Chiba, S. Molecular mechanism in a-glucosidase and glucoamylase. Bioscience, biotechnology, and biochemistry. 61, 1233-1239 (1997).

2. Humphries, M. J., Matsumoto, K., White, S. L. \& Olden, K. Inhibition of experimental metastasis by castanospermine in mice: blockage of two distinct stages of tumor colonization by oligosaccharide processing inhibitors. Cancer Res. 46, 5215-5222 (1986).

3. Sayce, A. C. et al. Iminosugars inhibit dengue virus production via inhibition of ER alphaglucosidases-not glycolipid processing enzymes. PLoS neglected tropical diseases. 10, e0004524 (2016).

4. Durantel, D., Alotte, C. \& Zoulim, F. Glucosidase inhibitors as antiviral agents for hepatitis B and C. Current opinion in investigational drugs (London, England: 2000) 8, 125-129 (2007).

5. Bischoff, $\mathrm{H}$. The mechanism of alpha-glucosidase inhibition in the management of diabetes. Clinical and investigative medicine. Medecine clinique et experimentale. 18, 303-311 (1995).

6. Park, S. H. et al. 1, 3-Oxazine as a chiral building block used in the total synthesis of (+)-1deoxynojirimycin and (2R, 5R)-dihydroxymethyl-(3R, 4R)-dihydroxypyrrolidine. Tetrahedron: Asymmetry. 26, 657-661 (2015).

7. Özil, M., Emirik, M., Etlik, S. Y., Ülker, S. \& Kahveci, B. A simple and efficient synthesis of novel inhibitors of alpha-glucosidase based on benzimidazole skeleton and molecular docking studies. Bioorganic chemistry. 68, 226-235 (2016).

8. Pogaku, V. et al. synthesis, molecular modelling, ADME prediction and anti-hyperglycemic evaluation of new pyrazole-triazolopyrimidine hybrids as potent a-glucosidase inhibitors. Bioorganic chemistry. 
93, 103307 (2019).

9. Khan, M. F. et al. The therapeutic voyage of pyrazole and its analogs: a review. European journal of medicinal chemistry. 120, 170-201 (2016).

10. Terrett, N. K., Bell, A. S., Brown, D. \& Ellis, P. Sildenafil (Viagra), a potent and selective inhibitor of type 5 cGMP phosphodiesterase with utility for the treatment of male erectile dysfunction. Bioorg Med Chem Lett. 6, 1819-1824 (1996).

11. Hassan, G. S., Abou-Seri, S. M., Kamel, G. \& Ali, M. M. Celecoxib analogs bearing benzofuran moiety as cyclooxygenase-2 inhibitors: design, synthesis and evaluation as potential anti-inflammatory agents. European journal of medicinal chemistry. 76, 482-493 (2014).

12. Ancel, J., Kaïm, E., Gadras, L., Grimaud, A., Jana, N. \& L. \& Studies towards the synthesis of Fipronil ${ }^{\circledR}$ analogues: improved decarboxylation of a-hydrazonoacid derivatives. Tetrahedron letters. 43, 83198321 (2002).

13. Smith, D. L., Forist, A. A. \& Dulin, W. E. 5-Methylpyrazole-3-carboxylic acid. The potent hypoglycemic metabolite of 3, 5-dimethylpyrazole in the rat. Journal of medicinal chemistry. 8, 350-353 (1965).

14. Faidallah, H. M., Khan, K. A. \& Asiri, A. M. Synthesis and biological evaluation of new 3trifluoromethylpyrazolesulfonyl-urea and thiourea derivatives as antidiabetic and antimicrobial agents. Journal of Fluorine Chemistry. 132, 131-137 (2011).

15. Shen, D. M. et al. Discovery of novel, potent, selective, and orally active human glucagon receptor antagonists containing a pyrazole core. Bioorganic \& medicinal chemistry letters. 21, 76-81 (2011).

16. Rikimaru, K. et al. A new class of non-thiazolidinedione, non-carboxylic-acid-based highly selective peroxisome proliferator-activated receptor (PPAR) y agonists: design and synthesis of benzylpyrazole acylsulfonamides. Bioorganic \& medicinal chemistry. 20, 714-733 (2012).

17. Huard, K. et al. Synthesis of spiropiperidine lactam acetyl-CoA carboxylase inhibitors. The Journal of organic chemistry. 77, 10050-10057 (2012).

18. Griffith, D. A. et al. Spirolactam-based acetyl-CoA carboxylase inhibitors: toward improved metabolic stability of a chromanone lead structure. Journal of medicinal chemistry. 56, 7110-7119 (2013).

19. Hernández-Vázquez, E., Aguayo-Ortiz, R., Ramírez-Espinosa, J. J., Estrada-Soto, S. \& Hernández-Luis, F. Synthesis, hypoglycemic activity and molecular modeling studies of pyrazole-3-carbohydrazides designed by a CoMFA model. European journal of medicinal chemistry. 69, 10-21 (2013).

20. Chaudhry, F. et al. In search of new a-glucosidase inhibitors: Imidazolylpyrazole derivatives. Bioorganic chemistry. 71, 102-109 (2017).

21. Xiong, Y. et al. Discovery of a Novel Glucagon Receptor Antagonist N-[(4-\{(1 S)-1-[3-(3, 5Dichlorophenyl)-5-(6-methoxynaphthalen-2-yl)-1 H-pyrazol-1-yl] ethyl\} phenyl) carbonyl]- $\beta$-alanine (MK-0893) for the Treatment of Type II Diabetes. Journal of medicinal chemistry. 55, 6137-6148 (2012).

22. Yoshida, T. et al. Discovery and preclinical profile of teneligliptin (3-[(2S, 4S)-4-[4-(3-methyl-1-phenyl1H-pyrazol-5-yl) piperazin-1-yl] pyrrolidin-2-ylcarbonyl] thiazolidine): a highly potent, selective, long- 
lasting and orally active dipeptidyl peptidase IV inhibitor for the treatment of type 2 diabetes. Bioorganic \& medicinal chemistry. 20, 5705-5719 (2012).

23. Peytam, F. et al. Design and synthesis of new imidazo [1, 2-b] pyrazole derivatives, in vitro aglucosidase inhibition, kinetic and docking studies. Molecular diversity. 24, 69-80 (2020).

24. Khanam, H. Bioactive Benzofuran derivatives: A review. European journal of medicinal chemistry. 97, 483-504 (2015).

25. Olomola, T. O., Mphahlele, M. J. \& Gildenhuys, S. Benzofuran-selenadiazole hybrids as novel aglucosidase and cyclooxygenase-2 inhibitors with antioxidant and cytotoxic properties.Bioorganic chemistry,103945(2020).

26. Dixit, M. et al. Synthesis of benzofuran scaffold-based potential PTP-1B inhibitors. Bioorganic \& medicinal chemistry. 15, 727-734 (2007).

27. Spasov, A. A. et al. Synthesis and biological evaluation of 2-acylbenzofuranes as novel aglucosidase inhibitors with hypoglycemic activity. Chem. Biol. Drug Des. 90, 1184-1189 (2017).

28. Liu, Y., Ma, L., Chen, W. H., Wang, B. \& Xu, Z. L. Synthesis of xanthone derivatives with extended $\pi-$ systems as a-glucosidase inhibitors: Insight into the probable binding mode. Bioorganic \& medicinal chemistry. 15, 2810-2814 (2007).

29. Li, G. L. et al. Toward potent a-glucosidase inhibitors based on xanthones: A closer look into the structure-activity correlations. European journal of medicinal chemistry. 46, 4050-4055 (2011).

30. Sepehri, N. et al. New acridine-9-carboxamide linked to 1, 2, 3-triazole-N-phenylacetamide derivatives as potent a-glucosidase inhibitors: design, synthesis, in vitro, and in silico biological evaluations. Medicinal Chemistry Research,1-10(2020).

31. Asgari, M. S. et al. Design, synthesis, biological evaluation, and docking study of new acridine-9carboxamide linked to 1, 2, 3-triazole derivatives as antidiabetic agents targeting aglucosidase. Journal of Heterocyclic Chemistry(2020).

32. Asemanipoor, N. et al. Synthesis and biological evaluation of new benzimidazole-1, 2, 3-triazole hybrids as potential a-glucosidase inhibitors. Bioorganic chemistry. 95, 103482 (2020).

33. Saeedi, M. et al. Design, synthesis, in vitro, and in silico studies of novel diarylimidazole-1, 2, 3triazole hybrids as potent a-glucosidase inhibitors. Bioorganic \& medicinal chemistry. 27, 115148 (2019).

34. Azimi, F. et al. Design and synthesis of novel pyrazole-phenyl semicarbazone derivatives as potential a-glucosidase inhibitor: Kinetics and molecular dynamics simulation study. International Journal of Biological Macromolecules(2020).

35. Bansal, G., Singh, S., Monga, V., Thanikachalam, P. V. \& Chawla, P. Synthesis and biological evaluation of thiazolidine-2, 4-dione-pyrazole conjugates as antidiabetic, anti-inflammatory and antioxidant agents. Bioorganic chemistry. 92, 103271 (2019).

36. Luthra, T. et al. Discovery of novel pyrido-pyrrolidine hybrid compounds as alpha-glucosidase inhibitors and alternative agent for control of type 1 diabetes. European journal of medicinal chemistry. 188, 112034 (2020). 
37. Kashtoh, H. et al. Dihydropyrano [2, 3-c] pyrazole: novel in vitro inhibitors of yeast a-glucosidase. Bioorganic chemistry. 65, 61-72 (2016).

38. Brayer, G. D., Luo, Y. \& Withers, S. G. The structure of human pancreatic a-amylase at 1.8 A resolution and comparisons with related enzymes. Protein Sci. 4, 1730-1742 (1995).

39. UniProt. the universal protein knowledgebase. Nucleic acids research. 45, D158-D169 (2017).

40. Song, Y. H. et al. Cinnamic acid amides from Tribulus terrestris displaying uncompetitive aglucosidase inhibition. European journal of medicinal chemistry. 114, 201-208 (2016).

41. Yamamoto, K., Miyake, H., Kusunoki, M. \& Osaki, S. Crystal structures of isomaltase from Saccharomyces cerevisiae and in complex with its competitive inhibitor maltose. The FEBS journal. 277, 4205-4214 (2010).

42. Lovell, S. C. et al. Structure validation by Ca geometry: $\phi, \psi$ and $C \beta$ deviation. Proteins: Structure, Function, and Bioinformatics. 50, 437-450 (2003).

43. Eisenberg, D., Lüthy, R. \& Bowie, J. U. in Methods in enzymology Vol. 277 396-404(Elsevier, 1997).

44. Azimi, F. et al. Identification of Essential 2D and 3D Chemical Features for Discovery of the Novel Tubulin Polymerization Inhibitors. Current topics in medicinal chemistry. 19, 1092-1120 (2019).

45. Schrödinger, L. Schrödinger Release 2015-4: Desmond molecular dynamics system, MaestroDesmond interoperability tools, DE Shaw Research. Schrödinger, New York, NY(2015).

\section{Figures}

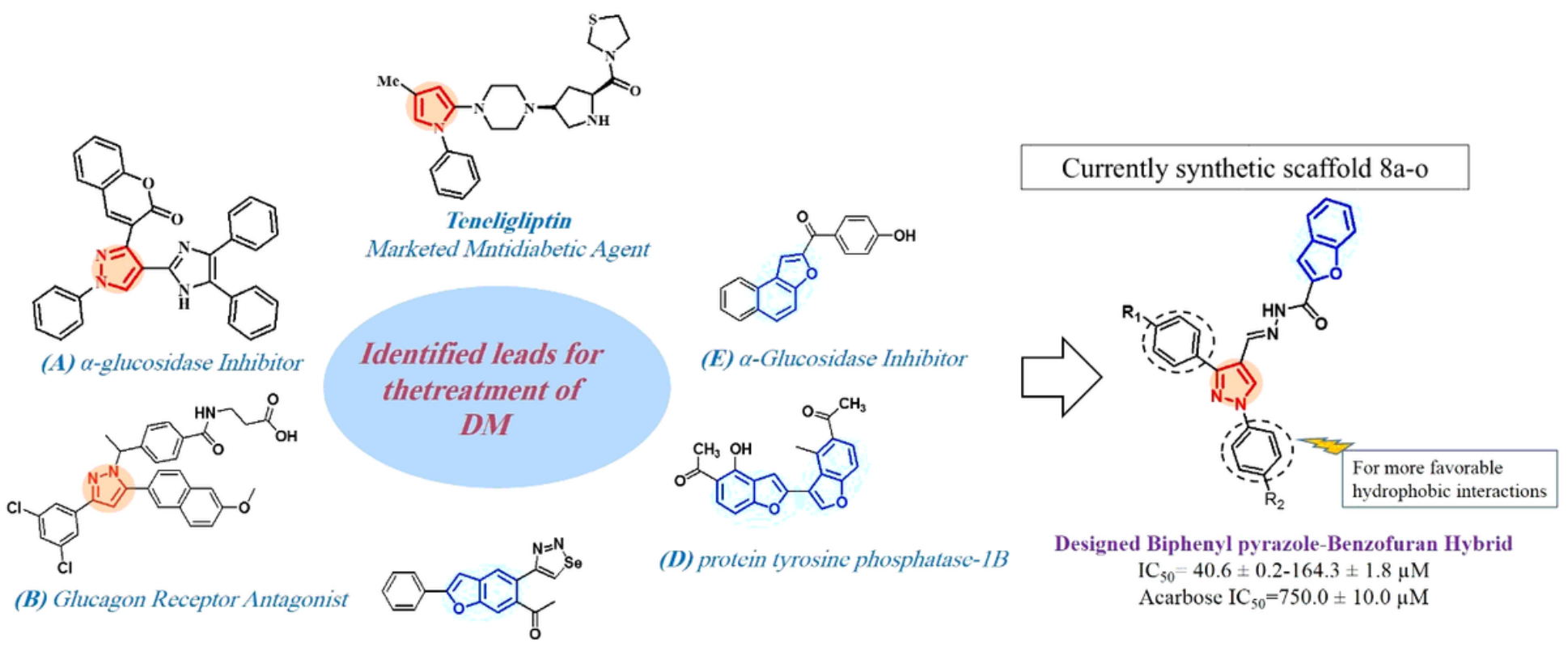

(C) $\alpha$-Glucosidase Inhibitor

\section{Figure 1}

Rationale of the current study. 
a)

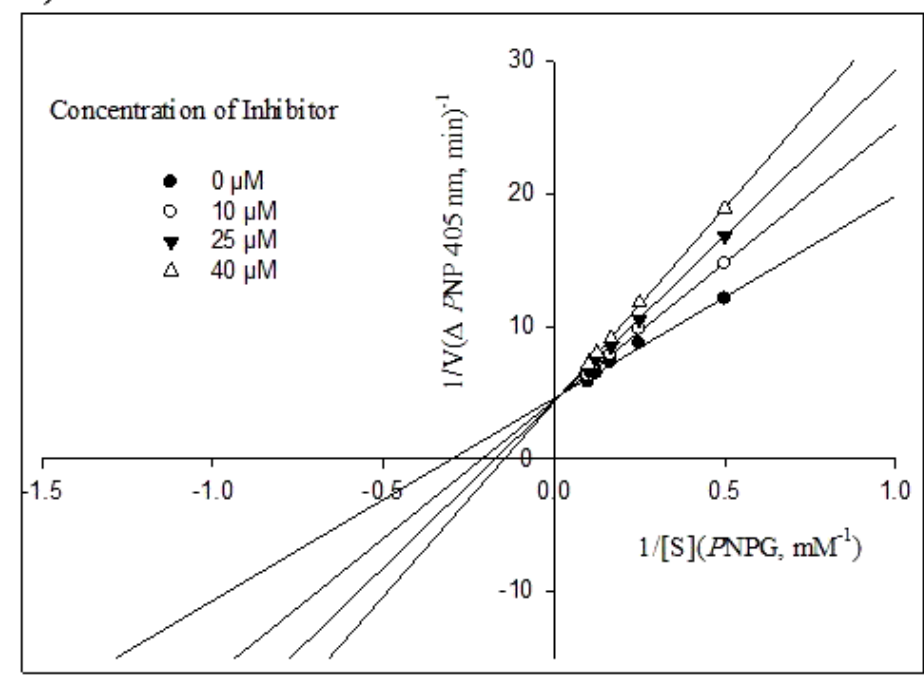

b)

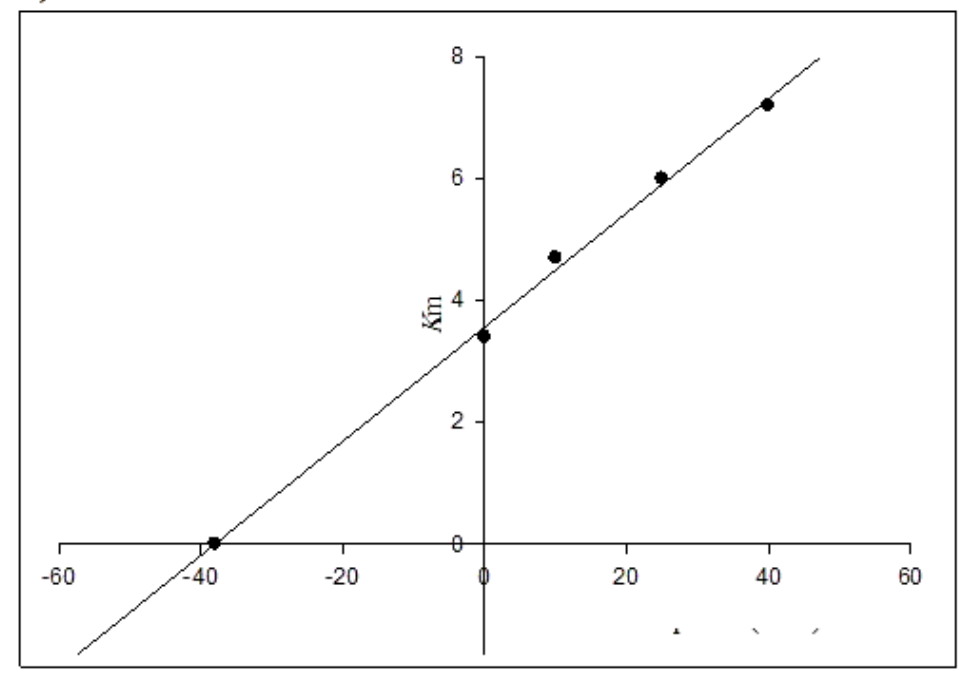

Figure 2

(a) Lineweaver-Burk plots for the inhibition of a-glucosidase by compound 8e. (b) The secondary plot between $\mathrm{Km}$ and various concentrations of compound $8 \mathrm{e}$. 


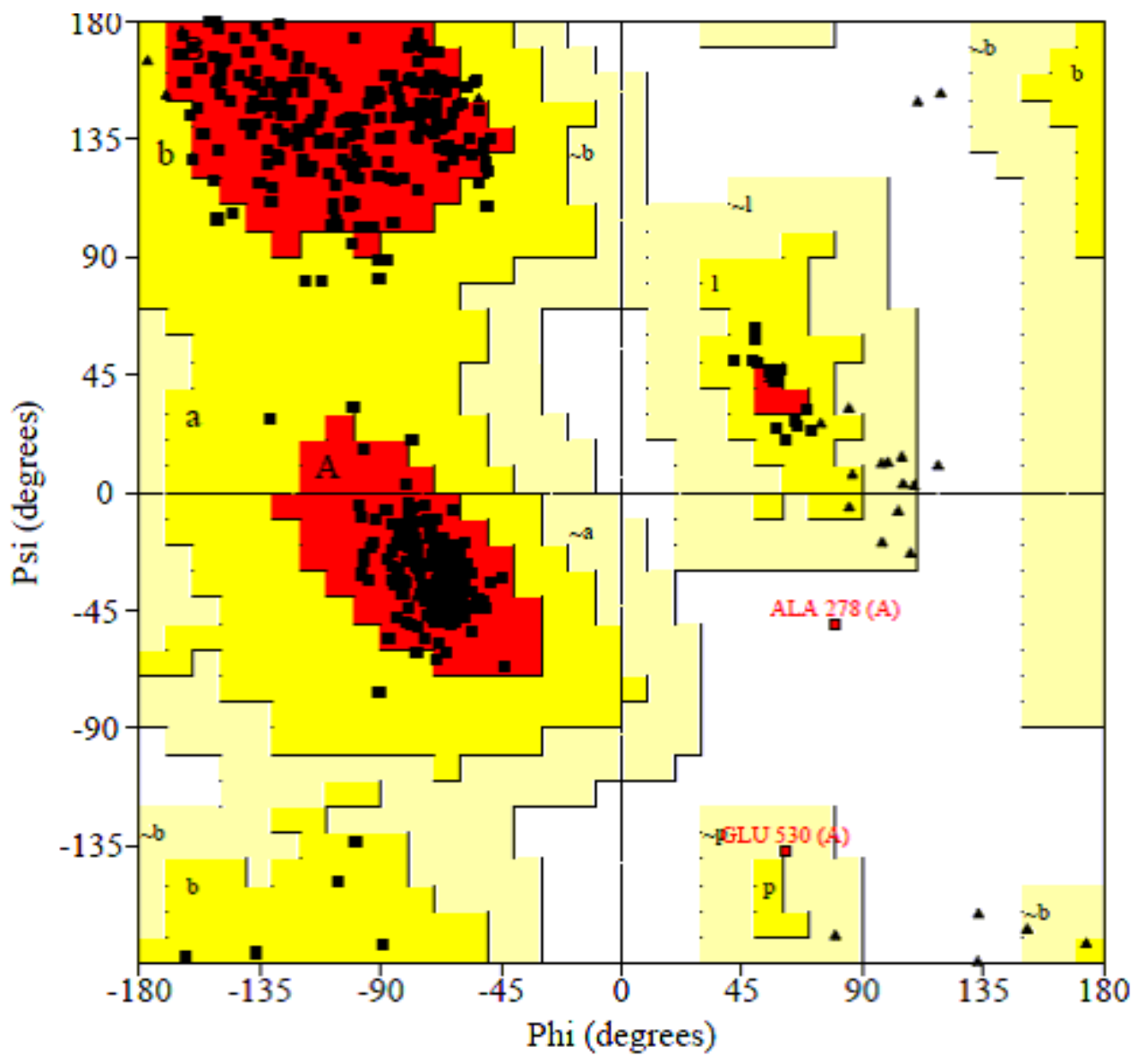

Plot statistics

$\begin{array}{lrr}\text { Residues in most favoured regions [A,B,L] } & 478 & 92.8 \% \\ \text { Residues in additional allowed regions [a,b,l,p] } & 35 & 6.8 \% \\ \text { Residues in generously allowed regions [ } \mathrm{a}, \sim \mathrm{b}, \mathrm{n}], \sim \mathrm{p}] & 1 & 0.2 \% \\ \text { Residues in disallowed regions } & 1 & 0.2 \% \\ \text { Number of non-glycine and non-proline residues } & 515 & 100.0 \% \\ \text { Number of end-residues (excl. Gly and Pro) } & 3 & 37 \\ \text { Number of glycine residues (shown as triangles) } & 28 \\ \text { Number of proline residues } & -583\end{array}$

Figure 3

Ramachandran plot of the modelled a-glucosidase enzyme.

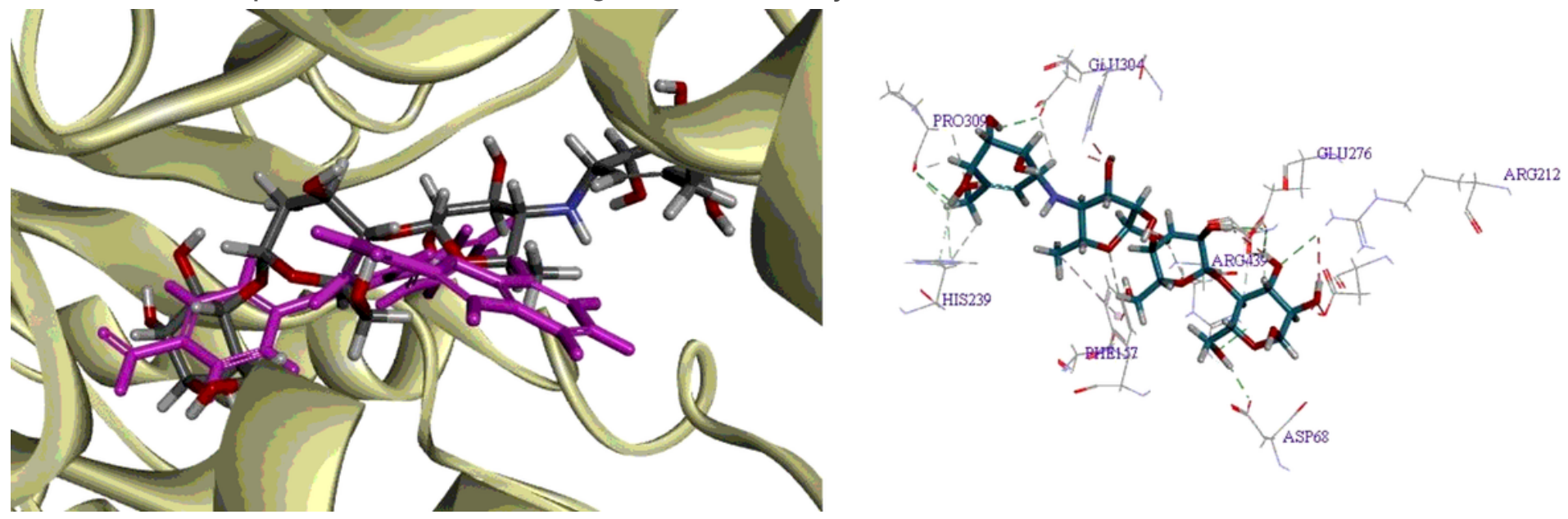


Figure 4

Acarbose (gray) and the most potent compounds $8 \mathrm{e}$ (pink) superimposed in the active site pocket of modeled a-glucosidase

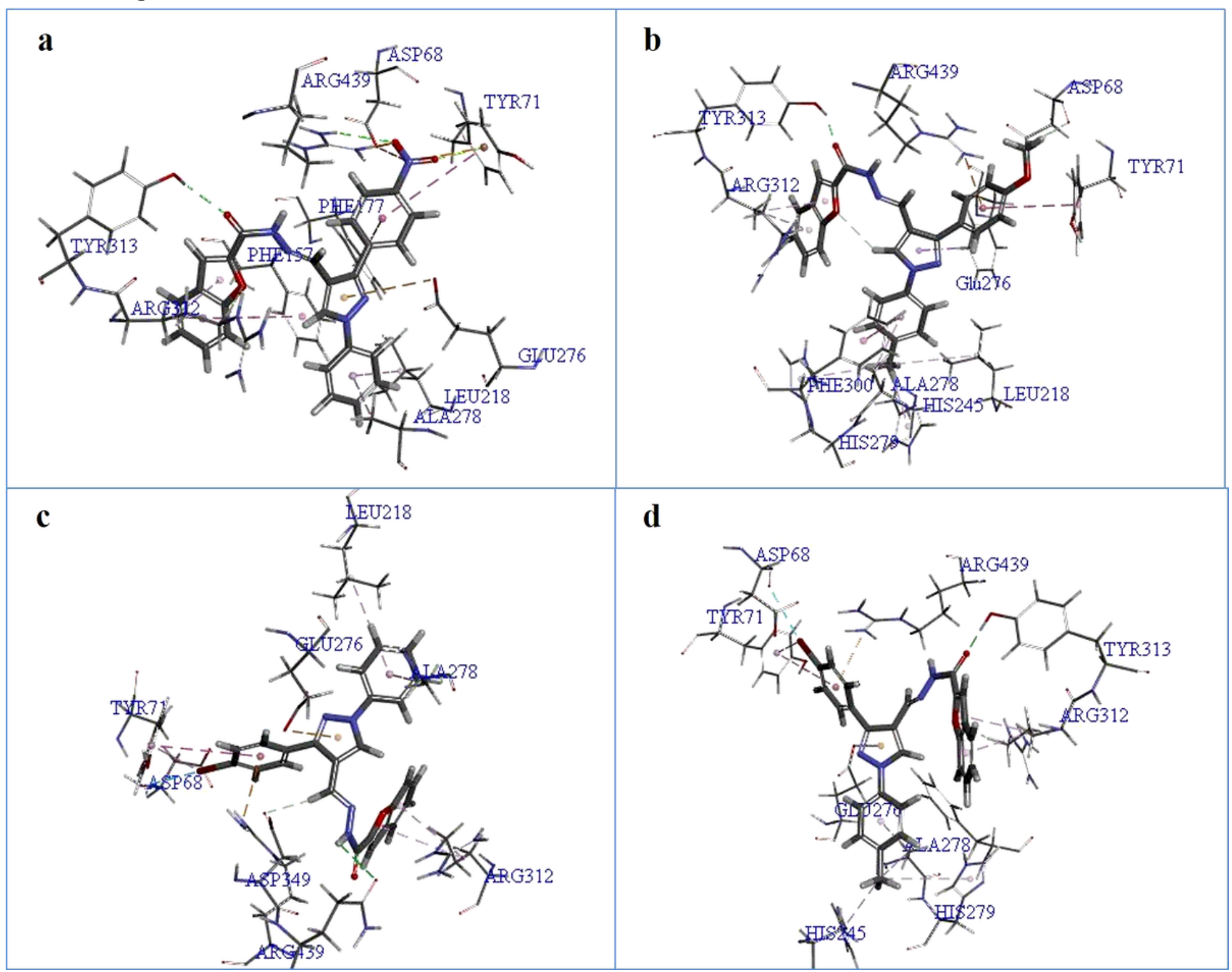

Figure 5

Docked conformer of compounds (a) 8e, (b) 8l, (c) $8 f$ and (d) $8 \mathrm{n}$ in the active site of a-glucosidase. 


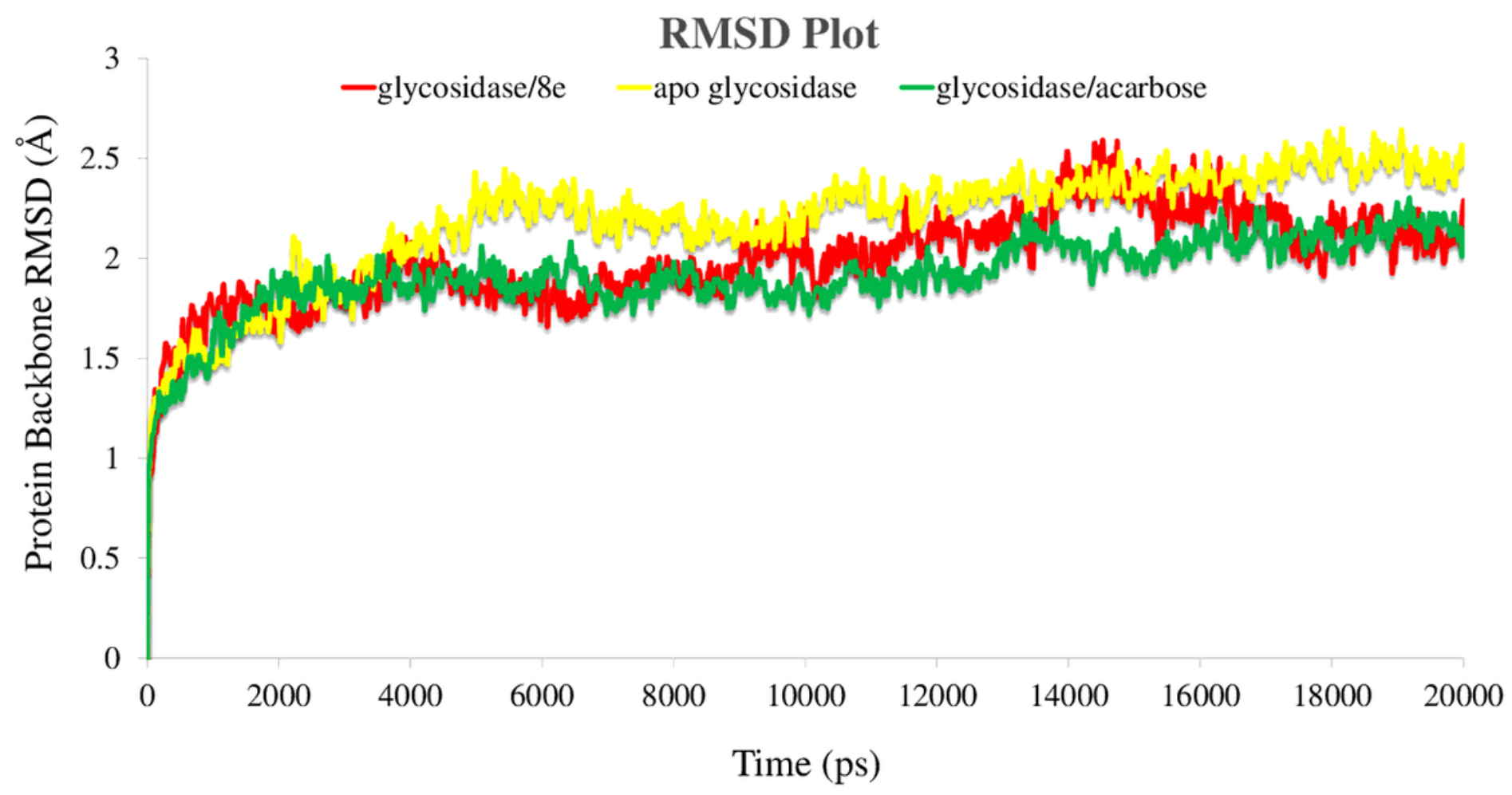

Figure 6

RMSD of the a-glycosidase backbone in complexed with acarbose (in green), compound $8 \mathrm{e}$ (in red) and the apo enzyme (in yellow) for over 20 ns MD simulation time. 


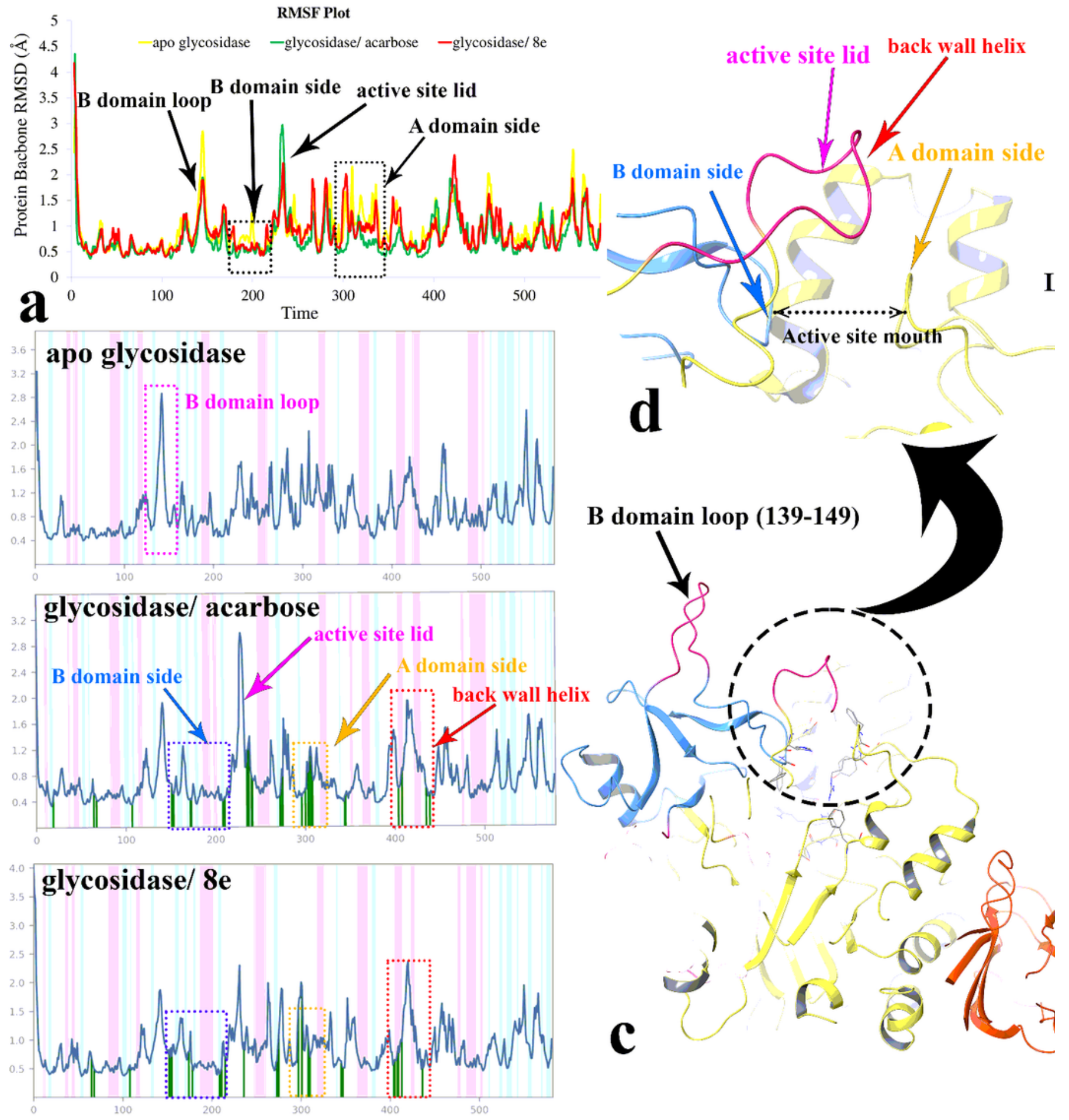

b

Residue Index

Figure 7

RMSF plot of the a-glycosidase backbone in complexed with compound $8 \mathrm{e}$ (in red) and acarbose (in green) and the apo enzyme for over $20 \mathrm{~ns}$ MD simulation time (a). ligand binding location for over $20 \mathrm{~ns}$ MD simulation time. $a$-helical and $ß$-strand regions are highlighted in red and blue backgrounds, respectively (b). 3D representation of a-glycosidase structure. Enzyme domain of $A, B$ and $C$ are colored in 
yellow, blue, and orange, respectively. The the flexible regions are colored in pink (c). Close-up representation of a-glycosidase active site (d).

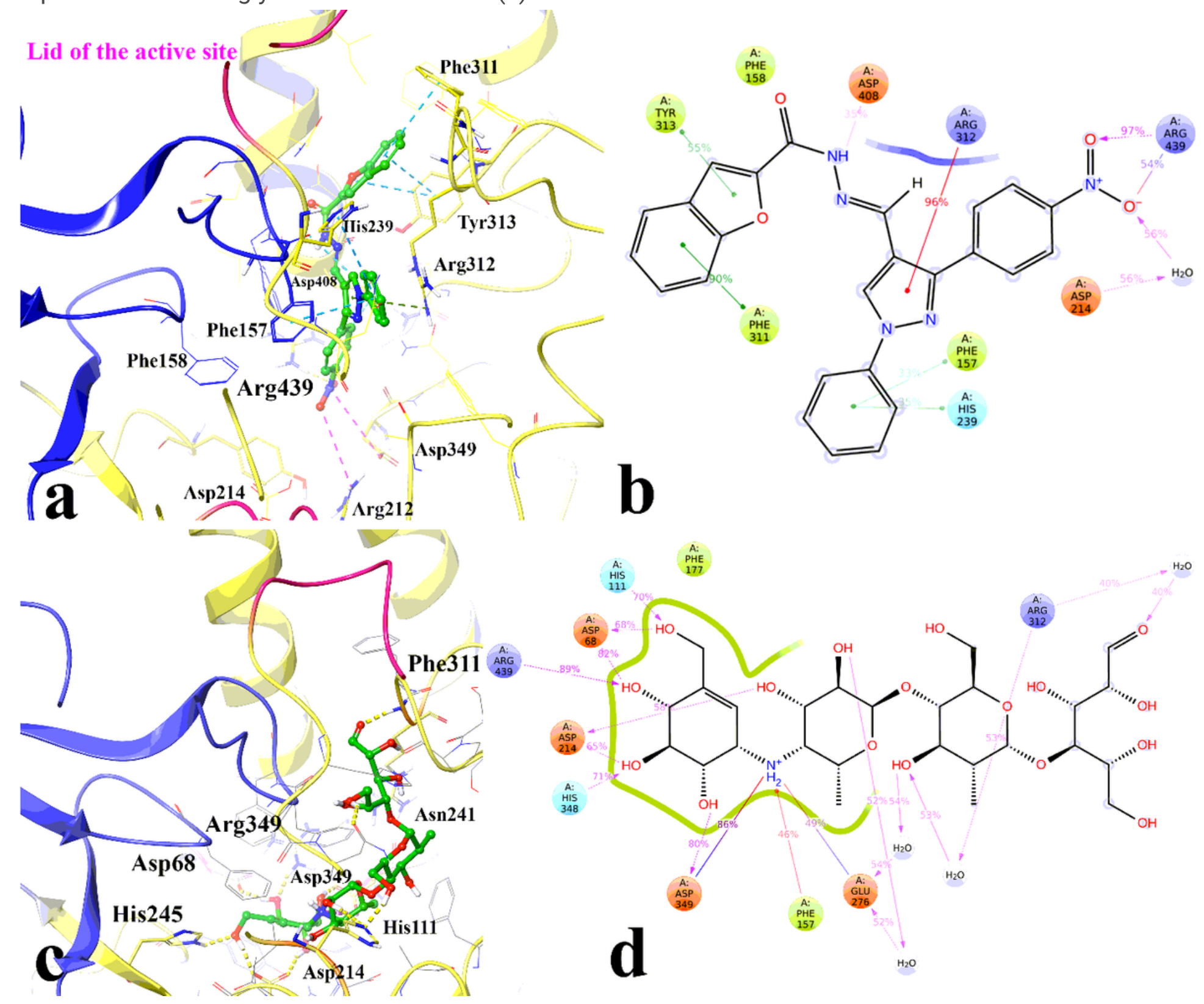

Figure 8

shows the detailed orientation and ligand atom interactions that occurred more than $30.0 \%$ of the simulation time during the equilibrated phase over a-glycosidase complexed with compound $8 \mathrm{e}(\mathrm{a}, \mathrm{b})$ and acarbose (c, d). Domain A, domain B and the flap region covered the mouth of the active site colored in yellow, blue and pink, respectively. 


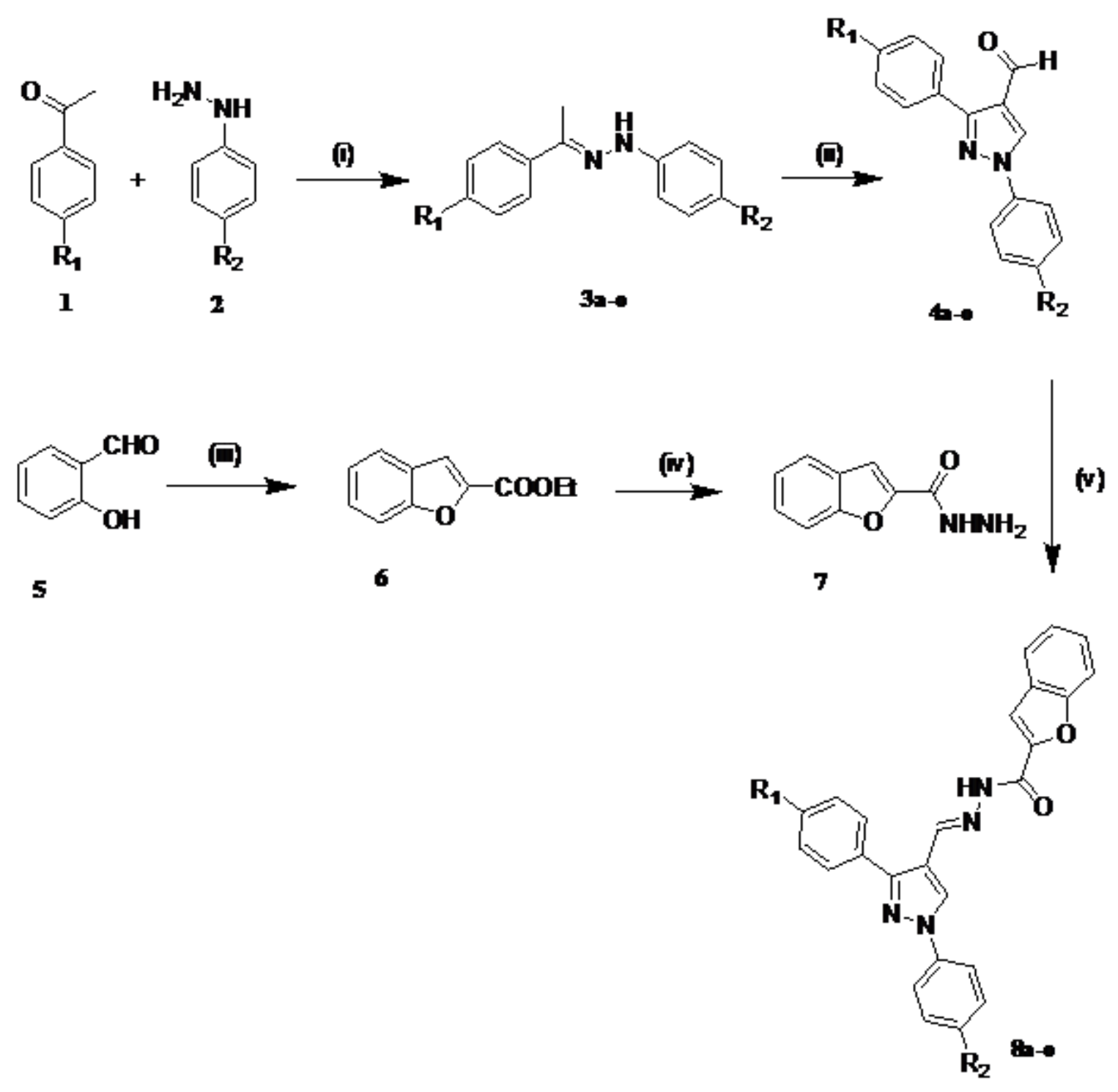

Figure 9

Scheme 1. Reagents and conditions for the synthesis of compounds 8a-n: (i) H2SO4, EtOH, reflux, 8-12 h, (ii) $\mathrm{POCl} 3, \mathrm{DMF}, 60-70{ }^{\circ} \mathrm{C}, 5-8 \mathrm{~h}$, (iii) Ethyl bromoacetate, $\mathrm{K} 2 \mathrm{CO}$, MeCN, reflux, $4 \mathrm{~h}$, (iv) $\mathrm{NH} 2 \mathrm{NH} 2 . \mathrm{H} 2 \mathrm{O}$, $\mathrm{EtOH}$, reflux, overnight, (v) AcOH, EtOH, reflux, 12-18 h.

\section{Supplementary Files}

This is a list of supplementary files associated with this preprint. Click to download.

- Supplementaryinformation.docx 